\title{
INTENSITAS PERDAGANGAN DAN KESELARASAN SIKLUS BISNIS DI ASEAN-4 DAN UNI EROPA*
}

\author{
Etty Puji Lestari \\ Fakultas Ekonomi Universitas Terbuka \\ Jalan Cabe Raya, Pondok Cabe, Pamulang, Tangerang 15418, Indonesia, Telepon (021)7490941 Ext 2106
}

Diterima 25 April 2011 / Disetujui 2 Oktober 2011

\begin{abstract}
The main objective of this research is to empirically analyze how the business cycle of ASEAN-4 (namely Indonesia, Malaysia, Thailand, and Philippines) economies are influenced by increased trade with European Union especially Netherland and Germany. Increased trade can lead business cycles across trading partners to be patterned in either direction, towards convergence or divergence. We used regression and vectorautoregression (VAR) methods for this research. Regression methods is based panel data whereas VAR is based on the time series analysis. There are four variables, which are business cycle, trade intensity, fiscal policy coordination and monetary policy coordination. This research conclude that trade intensity and monetary policy coordination are the major channel though which the business cycles of ASEAN-4 economies become synchronized. This has important implications for the formation of a currency union.
\end{abstract}

Keywords: business cycle, trade intensity, synchronization, monetary policy

\begin{abstract}
Abstrak: Tujuan utama penelitian ini, menganalisis secara empiris bagaimana siklus bisnis pada perekonomian di ASEAN-4 (Indonesia, Malaysia, Thailand dan Filipina) dipengaruhi oleh meningkatnya perdagangan dengan Uni Eropa. Peningkatan perdagangan dapat mempengaruhi pergerakan siklus bisnis mitra dagang menjadi konvergen atau divergen. Kita menggunakan metode regresi dan vectorautoregression (VAR) dalam penelitian ini. Metode regresi berbasis data panel sedangkan metode VAR berbasis pada analisis time series. Ada empat variabel yang digunakan yaitu siklus bisnis, intensitas perdagangan, koordinasi kebijakan fiskal dan koordinasi kebijakan moneter. Hasil penelitian menyimpulkan bahwa intensitas perdagangan dan koordinasi kebijakan moneter merupakan faktor dominan yang menyebabkan siklus bisnis pada perekonomian ASEAN-4 menjadi lebih selaras. Kondisi ini berimplikasi pentingnya penggunaan mata uang bersama.
\end{abstract}

Kata kunci: siklus bisnis, intensitas perdagangan, keselarasan, kebijakan moneter

\section{PENDAHULUAN}

Salah satu fenomena yang menandai era globalisasi adalah terjadinya proses integrasi di berbagai belahan dunia terutama dalam bidang ekonomi. Integrasi ini penting dilakukan masing-masing kawasan agar dapat bersaing dengan kawasan lainnya dalam menghadapi arus globalisasi dan liberalisasi perdagangan

\footnotetext{
${ }^{*}$ Hasil Penelitian Hibah Doktor DIKTI 2009.
}

dunia. Saat ini dapat dikatakan hampir semua kawasan telah melakukan kerjasama bidang ekonomi untuk memperlancar aktivitas investasi dan perdagangan dengan membentuk integrasi ekonomi (Achsani, 2008). Kerjasama ini dimaksudkan untuk memperkuat ekonomi kawasan dalam mempersiapkan diri memasuki perdagangan bebas WTO. Kesuksesan Uni Eropa juga menjadi pendorong semakin cepatnya perkembangan aktivitas blok-blok ekonomi dan perdagangan dari berbagai kawasan. 
ASEAN (Association of South East Asian Nation) yang didirikan di Bangkok pada tahun 1967 merupakan salah satu integrasi ekonomi yang ada di kawasan Asia Tenggara. Saat ini anggota ASEAN sudah mencapai 10 negara yaitu Indonesia, Malaysia, Philipina, Thailand, Singapura, Brunei Darussalam, Vietnam, Laos, Myanmar, dan Kamboja (www.asean.org). Mereka melakukan berbagai kerjasama berbagai bidang untuk meningkatkan kesejahteraan bersama. Upaya untuk meningkatkan pertumbuhan ekonominya dilakukan melalui berbagai kesepakatan.

Keberhasilan Uni Eropa membentuk satu pasar tunggal mengilhami ASEAN untuk melakukan hal yang sama. Pada KTT ASEAN Oktober 2002 di Kamboja, Singapura mengusulkan agar di tahun 2020 dibentuk pasar tunggal ASEAN mencontoh keberhasilan pembentukan pasar tunggal Eropa yang diberlakukan di kawasan Uni Eropa (Achsani, 2008). Ide ini akhirnya terwujud dengan ditandatanganinya Bali Concorde II pada tanggal 7 Oktober 2003 yang menyepakati terbentuknya ASEAN Community pada tahun 2020 dengan tiga pilar utama: ASEAN Security Community, ASEAN Economic Community dan ASEAN Socio-Culture Community.

Hubungan kerjasama ASEAN-Uni Eropa (UE) dirintis pada 1972 ketika ASEAN mem- bentuk Special Coordinating Committee of ASEAN Nations (SCCAN). Tujuannya adalah untuk mengadakan dialog dengan pihak Masyarakat Eropa (ME). ASEAN Brussels Committee (ABC) yang beranggotakan para Duta Besar negaranegara ASEAN di Brussels, berfungsi melaksanakan konsultasi antara kedua pihak. Selanjutnya ASEAN-EU membentuk Joint Cooperation Committee (JCC). Komite ini mengadakan pertemuan sekurang-kurangnya sekali dalam setahun dan membahas serta mengawasi pelaksanaan kerjasama di bidang ekonomi dan pembangunan.

Penurunan tarif yang terjadi di Asia Timur pada tahun 1980 memberikan sinyal positif bagi semua negara untuk meningkatkan volume perdagangannya. Kondisi ini berdampak terhadap peningkatan integrasi perdagangan terutama bagi negara yang sudah terintegrasi perekonomiannya seperti ASEAN yang tercermin dari meningkatnya Gross Domestic Bruto/GDP negara-negara di ASEAN (www.asean.org).

Statistik perdagangan di ASEAN juga menunjukkan peningkatan yang pesat, terutama setelah adanya penurunan tarif pada tahun 1980-an (lihat Rana (2007) serta Shin dan Wang (2004)). Pada kurun waktu tersebut integrasi perdagangan antarnegara menunjukkan performa tertinggi yang berarti semakin besar pula terjadinya keselarasan siklus bisnis. Isu kesela-

Tabel 1. Nilai Perdagangan ASEAN dengan Negara Lain (dalam milyar \$)

\begin{tabular}{|c|c|c|c|c|c|c|}
\hline \multirow[t]{2}{*}{ Negara Mitra } & \multicolumn{3}{|c|}{ Nilai } & \multicolumn{3}{|c|}{$\begin{array}{c}\text { Persentase dari total Perdagangan } \\
\text { ASEAN }\end{array}$} \\
\hline & Ekspor & Impor & Total & Ekspor & Impor & Total \\
\hline ASEAN & $189.176,8$ & $163.594,5$ & $352.771,4$ & 25,2 & 25,0 & 25,1 \\
\hline Jepang & $81.284,9$ & $80.495,6$ & $161.780,5$ & 10,8 & 12,3 & 11,5 \\
\hline USA & $96.943,5$ & $64.252,5$ & $161.196,0$ & 12,9 & 9,8 & 11,5 \\
\hline European Union-25 & $94.471,8$ & $66.118,1$ & $160.589,9$ & 12,6 & 10,1 & 11,4 \\
\hline China & $65.010,3$ & $74.950,9$ & $139.961,2$ & 8,7 & 11,5 & 10,0 \\
\hline Korea & $25.670,0$ & $26.849,7$ & $52.519,6$ & 3,4 & 4,1 & 3,7 \\
\hline Australia & $23.148,5$ & $13.262,8$ & $36.411,4$ & 3,1 & 2,0 & 2,6 \\
\hline India & $18.928,1$ & $9.774,6$ & $28.702,7$ & 2,5 & 1,5 & 2,0 \\
\hline Taiwan & $9.032,0$ & $12.876,9$ & $21.908,9$ & 1,2 & 2,0 & 1,6 \\
\hline Hong Kong, SAR & $13.784,0$ & $6.409,0$ & $20.193,0$ & 1,8 & 1,0 & 1,4 \\
\hline Total sepuluh besar & $617.449,9$ & $518.584,6$ & $1.136 .034,6$ & 82,2 & 79,3 & 80,9 \\
\hline Lainnya & $133.257,9$ & $135.513,2$ & $268.771,1$ & 17,8 & 20,7 & 19,1 \\
\hline Total & $750.707,8$ & $654.097,8$ & $1.404 .805,7$ & 100,0 & 100,0 & 100,0 \\
\hline
\end{tabular}

Sumber: ASEAN Database Trade, 2007 
rasan siklus bisnis menjadi sangat penting karena jika intensitas perdagangan di negaranegara ASEAN meningkat dan siklus bisnis bergerak sama maka kemungkinan diberlakukannya mata uang bersama akan semakin besar.

Data perdagangan yang dilakukan oleh ASEAN dengan Uni Eropa pada tahun 2006 mencatat nilai ekspor ASEAN mencapai 94.471,8 milyar US\$, sedangkan nilai impornya 66.118,1 milyar US\$ (lihat Tabel 1). Apabila diprosentase maka share perdagangan ini mencapai 12,6 persen untuk ekspor dan 10,1 untuk impor dari nilai keseluruhan perdagangan ASEAN (www.asean.org). Pangsa ini menduduki posisi kedua di bawah Amerika Serikat. Tingginya share ekspor negara ASEAN kepada Uni Eropa ini membuktikan bahwa kegiatan perdagangan dengan Eropa memberikan prospek yang sangat baik terhadap kinerja perdagangan ASEAN.

Salah satu hal yang berkaitan dengan masalah integrasi ekonomi adalah kegiatan perdagangan dan keselarasan (syncronization) siklus bisnis. Siklus bisnis (business cycle) atau juga dikenal sebagai siklus ekonomi (economic cycle) adalah pola jangka panjang pertumbuhan (ekspansi) dan resesi (kontraksi) ekonomi. Menurut penelitian yang dilakukan oleh Centre for International Business Cycle Research di Universitas Columbia New York, antara tahun 1854 dan 1945 ekspansi ekonomi rata-rata berlangsung 29 bulan sementara masa kontraksi berlangsung 21 bulan (Botha, 2004). Namun demikian, sejak berakhirnya Perang Dunia II, siklus ekspansi telah memanjang hingga hampir dua kali lipat, yaitu rata-rata 50 bulan, sementara siklus kontraksi memendek hingga rata-rata berlangsung hanya 11 bulan.

Siklus bisnis juga dapat didefinisikan sebagai deviasi dari output terhadap tren (Mithal, 2004; Botha, 2004). Dalam konteks ini timbul periode ekspansi dan kontraksi terhadap aktivitas perekonomian. Siklus bisnis berdampak terhadap inflasi, pengeluaran pemerintah, ketenagakerjaan, penjualan, produksi dan beberapa aspek perekonomian (Botha, 2004). Siklus bisnis terdiri dari beberapa tahapan yang berbeda yaitu fase ekspansi, fase kontraksi, dan fase recovery.
Fase ekspansi merupakan fase awal di mana perekonomian mengalami ekspansi melebihi ketinggian siklus sebelumnya. Di dalam ekspansi terdapat beberapa periode termasuk dalam periode peningkatan dan penurunan pertumbuhan ekonomi yang sering disebut siklus pertumbuhan (Botha, 2004). Ekspansi merupakan suatu periode di mana permintaan dan produksi mengalami peningkatan dan kepercayaan konsumen juga meningkat sehingga angka penjualan juga meningkat. Inflasi dan suku bunga juga mengalami kenaikan selama periode ekspansi.

Fase kedua adalah fase kontraksi. Ekspansi bisnis meningkat sampai puncaknya sesudahnya diikuti oleh fase kontraksi. Selama fase ini beberapa faktor seperti penjualan, harga, produksi dan tenaga kerja mulai menurun. Penurunan ini biasanya akan diikuti oleh penurunan suku bunga. Apabila penurunan ini terjadi secara drastis dan dalam jangka panjang maka akan terjadi resesi. Resesi ini biasanya didefinisikan sebagai penurunan BC secara dua kuartal berturut-turut. Ini terjadi biasanya kurang dari satu tahun sampai satu tahun dan berimbas pada kontraksi beberapa sektor ekonomi. Resesi dimulai pada puncak siklus bisnis dan berakhir titik terendah/trough.

Fase ketiga adalah fase pemulihan (recovery). Adakalanya dalam suatu perekonomian terjadi perulangan permintaan dan kenaikan produksi. Fase recovery bergerak sampai ke ekspansi periode baru dan siklus bisnis dimulai kembali. Recovery merupakan fase transisional yang dimulai dari titik ekonomi terendah atau trough sampai perekonomian pulih kembali dan kembali ke semula. Secara umum, pertumbuhan yang paling kuat terjadi pada fase recovery namun durasinya paling pendek dibanding fase resesi (Botha, 2004). Menurut teori siklus bisnis, saat terjadi booming ekonomi, kredit akan bergerak tak terkendali, moral hazard tumbuh sehingga masa kemakmuran akan berbalik menjadi krisis. Siklus bisnis dianggap sebagai irama ekonomi dan juga sebagai bagian dari ketidakseimbangan moneter.

Peningkatan perdagangan dengan beberapa negara terutama dengan negara-negara di Asia Timur semakin berkembang. Beberapa 
studi menyatakan bahwa peningkatan perdagangan yang cepat akan menyebabkan peningkatan pertumbuhan pendapatan yang cepat pula. Implikasi penting dari meningkatnya perdagangan adalah pada negara yang terintegrasi perdagangannya maka kinerja makroekonominya lebih meningkat dibanding negara yang belum terintegrasi. Pengaruh penting negara mitra dagang menjadi faktor yang esensial untuk mengetahui fluktuasi siklus bisnis perekonomian domestik (Shin dan Wang, 2005). Meningkatnya kegiatan perdagangan dengan negara lain dapat menyebabkan siklus bisnis mereka bergerak secara divergen maupun konvergen (Fiess, 2005). Sebagai contoh jika perdagangan terjadi seperti teori Heckser-Ohlin atau Ricardo maka semakin besar spesialisasi industri berakibat pada berkurangnya keselarasan siklus bisnis (lihat Frankel dan Rose (1998), Rana (2007), Rana (2006), Shin dan Wang (2004) serta Teng dan Way (2005)). Sebaliknya, jika peningkatan perdagangan terjadi pada perdagangan intra industri maka siklus bisnis dengan mitra dagang akan menjadi selaras. Keselarasan siklus bisnis (business cycle syncronization) mengindikasikan adanya keselarasan pergerakan variabel-variabel makroekonomi.

Analisis tentang pergerakan siklus bisnis menarik dikaji karena akan mempengaruhi kebijakan ekonomi dan kelembagaan. Banyak peneliti percaya bahwa ada korelasi yang kuat antara integrasi perdagangan dengan siklus bisnis. Beberapa peneliti menganalisis pergerakan pada agregat ekonomi makro yang dialami suatu negara yang terintegrasi secara ekonomi dengan negara lain. Ada tiga alasan mengapa analisis tersebut dilakukan (Loayza, et al, 2001). Pertama, shock yang dihadapi oleh suatu negara biasanya akan berdampak kepada negara lain melalui integrasi perdagangan dan transaksi pasar uang. Kedua, negara yang terintegrasi dalam suatu group apabila salah satu anggotanya mengalami shock maka akan menimbulkan dampak yang sama dengan negara lain dalam group tersebut. Ketiga, shock yang melanda sektor tertentu mungkin akan menyebabkan pergerakan dalam agregat output jika struktur ekonomi negara sama.

Dampak dari peningkatan integrasi perda- gangan dan korelasinya dengan siklus bisnis antara dua negara tergantung pada dominasi inter industri dan intra industri. Semakin besar perdagangan inter industri cenderung akan mengurangi korelasi siklus bisnis antar mitra dagang. Sementara itu peningkatan perdagangan intra industri akan cenderung meningkatkan korelasi siklus bisnis (literatur lebih lanjut lihat Zebregs, 2004; Cortinhas, 2007; Shin dan Wang, 2004; Teng dan Way, 2005; dan Rana, 2007). Secara teoritis integrasi perdagangan akan menimbulkan efek terhadap peningkatan perdagangan, peningkatan efisiensi ekonomi, dan daya saing yang tinggi yang pada gilirannya akan meningkatkan kesejahteraan.

Sementara itu terdapat beberapa peneliti yang memberikan argumentasi sebaliknya. Kajian yang dilakukan oleh Eric (2007) menyatakan bahwa negara yang terintegrasi sektor perdagangannya akan cenderung menurunkan siklus bisnisnya. Hal ini terjadi karena adanya spesialisasi industri yang diterapkan oleh negara tersebut. Spesialisasi industri akan memperkuat daya saing dan kemandirian ekonomi negara yang bersangkutan sehingga tidak tergantung dengan negara lain.

Siklus bisnis diyakini akan bergerak sepanjang waktu sebagai dampak dari adanya globalisasi (Botha, 2004). Salah satu perubahan yang terjadi adalah keselarasan siklus bisnis antar negara, terutama negara yang melakukan integrasi perdagangan seperti yang terjadi di ASEAN-4 (Indonesia, Malaysia, Thailand dan Filipina) dan Uni Eropa. Faktor tersebut diyakini dapat mempengaruhi volatilitas siklus bisnis dan secara alamiah memungkinkan terjadinya chaos pada siklus bisnis. Penelitian ini ingin membuktikan bagaimana keselarasan siklus bisnis di ASEAN-4 dipengaruhi oleh meningkatnya intensitas perdagangan dengan Uni Eropa pada periode $1980-2008$.

\section{METODE PENELITIAN}

Penelitian ini menggunakan sampel enam negara yaitu ASEAN-4 yang terdiri dari Indonesia, Malaysia, Thailand dan Filipina serta dua nega- 
ra Uni Eropa yaitu Belanda dan Jerman. ${ }^{1}$ Rentang waktu yang dipilih adalah tahun 1980 sampai 2008. Sumber data diperoleh dari International Financial Statistic, Direction of Trade dan Government Financial Statistic terbitan International Monetary Funds.

Penelitian ini menggunakan dua pengujian yaitu pengujian regresi dengan data panel dan pengujian Vector Autoregression (VAR). Variabel yang digunakan ada empat yaitu siklus bisnis (BC) atau siklus bisnis, intensitas perdagangan, koordinasi kebijakan fiskal dan koordinasi kebijakan moneter. Pemilihan keempat variabel tersebut didasarkan pada previous study yang dilakukan oleh Shin dan Wang (2004), Teng dan Way (2005), dan Rana (2007).

Variabel siklus bisnis (business cycle/BC) diperoleh dari koefisien korelasi Produk Domestik Bruto/PDB bilateral menggunakan pendekatan five year moving average, mengikuti kajian yang sudah dilakukan oleh Shin dan Wang (2004), Rana (2007) serta Teng dan Way (2005). Variabel intensitas perdagangan (trade intensity/TI) diperoleh dari perhitungan terms of trade yang diolah menggunakan formula Frankel dan Rose (1998). Perhitungan ini mengadopsi penelitian dilakukan oleh Teng dan Way (2005) serta Shin dan Wang (2005). Variabel intensitas perdagangan dihitung dengan formula sebagai berikut:

$w t_{t}(i, j)=\frac{x_{i j t}+m_{i j t}}{X_{i t}+M_{i t}+X_{j t}+M_{j t}}$

dimana $X_{\mathrm{ijt}}=$ total nominal ekspor dari negara $i$ ke negara $j$ pada periode waktu $t$; Mijt $=$ total nominal impor dari negara $i$ ke negara $j$ pada periode waktu $t ; X_{i j}+\mathbf{M} i j=$ nilai keseluruhan ekspor dan impor negara i (j) pada periode waktu t.

Selanjutnya untuk melihat keselarasan pergerakan siklus bisnis, maka penelitian ini me-

\footnotetext{
${ }^{1}$ Perlu diingat bahwa ASEAN didirikan pada tanggal 8 Agustus 1967 sehingga pilihan dimulainya penelitian pada tahun 1980 didasarkan asumsi bahwa data perdagangan untuk ASEAN-4 sudah tersedia. sedangkan untuk sampel Uni Eropa dipilih sampel dua negara terbesar yang melakukan kegiatan perdagangan dengan ASEAN yaitu Jerman dan Belanda (lihat www.asean.org)
}

masukkan variabel koordinasi kebijakan fiskal dan kebijakan moneter dalam analisis. Hal ini dilakukan dengan asumsi bahwa semakin meningkat intensitas perdagangan akan semakin memerlukan koordinasi kebijakan-kebijakan tersebut. Dampak dari pengenaan kebijakankebijakan tersebut akan berpengaruh terhadap pergerakan siklus bisnis.

Pemilihan variabel koordinasi kebijakan fiskal (fiscal policy coordination/FPC) diperoleh dari perhitungan koefisien korelasi rasio pengeluaran pemerintah dengan PDBsepasang negara menggunakan pendekatan five year moving average. Sementara itu koordinasi kebijakan moneter (monetary policy coordination/MPC) diukur dari koefisien korelasi bilateral interest rate dengan pendekatan five year moving average seperti yang digunakan Rana (2007).

Penambahan beberapa variabel tersebut, dapat dibuat model persamaan, yaitu:

$$
\begin{aligned}
B C(i, j)_{t}= & \alpha_{0}+\alpha_{1} \cdot T I(i, j)_{t}+\alpha_{2} F I S(i, j)_{t}+ \\
& \alpha_{3} \operatorname{MON}(i, j)_{t}+\varepsilon i j_{t}
\end{aligned}
$$

dimana BC adalah siklus bisnis; TI (trade intensity) adalah intensitas perdagangan yang dihitung menggunakan formula Frankel dan Rose (1998); FIS adalah koordinasi kebijakan fiskal dan MON adalah variabel kordinasi kebijakan moneter. Penelitian menggunakan data panel dengan metode seemingly unrelated regression/ SUR dalam analisisnya seperti yang digunakan Teng dan Way (2005).

\section{Pengujian Regresi Data Panel}

Model perhitungan regresi menggunakan data panel. Data panel atau sering disebut pooled data merupakan kombinasi dari data time series yang memiliki observasi temporal biasa pada suatu unit analisis dengan data cross section yang memiliki observasi-observasi pada suatu unit analisis pada suatu titik waktu tertentu. Ciri khusus yang melekat pada time series adalah adanya urutan numerik di mana interval antar observasi atas sejumlah variabel bersifat konstan dan tetap, sedangkan pada data cross section adalah suatu unit analisis pada suatu titik waktu tertentu dengan observasi atas 
sejumlah variabel (Kuncoro, 2007). Dengan mengakomodasi informasi baik yang terkait dengan variabel-variabel cross section maupun time series, data panel secara substansial mampu menurunkan masalah omitted-variables, model yang mengabaikan variabel yang relevan (Gujarati, 2003).

Selain alasan pragmatis, metode data panel digunakan untuk mengatasi interkorelasi di antara variabel-variabel bebas yang pada akhirnya dapat mengakibatkan tidak tepatnya penaksiran regresi. Dalam sebuah penelitian terkadang ditemukan suatu persoalan mengenai ketersediaan data (data avaibility) untuk mewakili variabel yang digunakan dalam penelitian. Melalui penggabungan data time series dan cross section (pooling), maka jumlah observasi bertambah secara signifikan tanpa melakukan treatment apapun terhadap data.

Penggunaan metode data panel ini memiliki beberapa keunggulan, pertama, data panel mampu memperhitungkan heterogenitas individu secara eksplisit dengan mengijinkan variabel spesifik individu. Kedua, kemampuan mengontrol heterogenitas individu ini, pada gilirannya menjadikan data panel dapat digunakan untuk menguji dan membangun model perilaku yang lebih kompleks. Ketiga, data panel mendasarkan diri pada observasi cross section yang berulang-ulang (time series), sehingga metode data panel cocok untuk digunakan sebagai study of dynamic adjusment. Keempat, tingginya jumlah observasi memiliki implikasi pada data yang lebih informatif, lebih variatif, kolinearitas antarvariabel yang semakin berkurang, dan peningkatan derajat kebebasan (degree of freedom), sehingga dapat diperoleh hasil estimasi yang lebih efisien. Kelima, data panel dapat digunakan untuk mempelajari model-model perilaku yang kompleks. Keenam, data panel dapat meminimalisir bias yang mungkin ditimbulkan oleh agregasi data individu. Keunggulan-keunggulan tersebut di atas memiliki implikasi pada model yang dipakai dan tidak harus dilakukan pengujian asumsi klasik dalam model data panel, sesuai apa yang ada dalam beberapa literatur yang digunakan dalam penelitian ini (Unair, 2009; Gujarati, 2003).

\section{Pengujian Vector Autoregression}

VAR merupakan alat analisis yang dapat digunakan baik untuk memproyeksikan sistem variabel-variabel runtut waktu maupun menganalisis dampak dinamis dari faktor gangguan yang terdapat dalam sistem variabel tersebut. Selain itu, VAR juga berguna untuk mengetahui adanya hubungan timbal balik (interrelationship) antara variabel-variabel ekonomi, maupun di dalam pembentukan model ekonomi berstruktur (Hadi, 2003). Dengan menggunakan VAR, penelitian ini mencoba mencari ada tidaknya korelasi timbal balik (interrelationship) antara variabel intensitas perdagangan, perdagangan intra industri, koordinasi kebijakan fiskal, koordinasi kebijakan moneter dan kebijakan nilai tukar dengan keselarasan siklus bisnis di antara negara dalam sampel.

Kerangka analisis yang praktis dalam VAR akan memberikan informasi yang sistematis dan mampu menaksir dengan baik informasi dalam persamaan yang dibentuk dari data time series. Selain itu perangkat estimasi dalam model VAR mudah digunakan dan diintepretasikan. Perangkat estimasi yang akan digunakan dalam model VAR ini adalah fungsi impulse respon dan variance decompotition. Ada beberapa keuntungan dari metode VAR (Gujarati, 2003) yaitu: (1) VAR mampu melihat lebih banyak variabel dalam menganalisis fenomena ekonomi jangka pendek dan jangka panjang; (2) VAR mampu mengkaji konsistensi model empirik dengan teori ekonometrika, dan (3) VAR mampu mencari pemecahan terhadap persoalan variabel runtun waktu yang tidak stasioner (non stasionary) dan regresi lancung (spurious regresion) atau korelasi lancung (spurious correlation) dalam analisis ekonometrika (Gujarati, 2003).

Pendekatan tradisional yang selama ini sering dilakukan dalam menentukkan bentuk hubungan jangka panjang adalah penggunaan analisis kointegrasi. Sementara model lain yang kemukakan oleh Sims et,al (1991) dikenal dengan VAR (Gujarati, 2003). Metodologi ini didasarkan atas reaksi terhadap pendekatan ekonometri tradisional untuk menangani model simultan (multi-equation simultaneous models). Kunci penting dari pendekatan ini adalah 
pembagian variabel-variabel menjadi variabel endogen ke dalam model dan variabel yang diperlakukan sebagai variabel eksogen. VAR telah banyak digunakan dalam ekonomi makro. VAR mampu melakukan peramalan lebih baik dibanding model persamaan struktural (Gujarati, 2003). Misalnya model VAR sebagai berikut.

$Y_{t}=\Gamma Y_{t-1}+\varepsilon_{t}$

dimana vektor $Y t=\left|Y_{t}, Z_{t}\right|$. Lakukan turunan pertama menjadi :

$y_{t}-y_{t-1}=(\Gamma-1) y_{t-1}+\varepsilon_{t} t$ dan

$\Delta y t=\Pi y_{t-1}+\varepsilon_{t}$

Jika semua variabel terintegrasi I(1) maka semua variabel $M$ pada sisi kiri adalah $I(0)$. Matrik $\Pi$ menghasilkan kombinasi linier dari variabel dalam $Y_{t}$. Namun seperti yang dilihat, tidak semua kombinasi linier terkointegrasi meskipun model representasi VAR dipastikan ada (Handoyo, 2002). Jika mengasumsikan model ini sebagai unrestricted VAR maka hasil matriks koefisien harus diperingkat. Implikasinya, jika variabel benar-benar terkointegrasi maka koefisien matriksnya tidak akan kehilangan kesesuaiannya (goodnes of fit) (Greene, 2000).

Jika $X_{t}$ menjadi kolom vektor dari sejumlah p komponen dengan I maka sistem yang dapat ditulis dalam jumlah order VAR yang terbatas (restricted VAR) seperti berikut :

$\Delta X_{t}=\mu+\Pi x_{t-1}+\ldots+T k \Delta x_{t-k}+\varepsilon_{t}$

dimana $\mathrm{t}=1,2,3 \ldots \mathrm{t}$ dan $\varepsilon_{t}$ independen, $\mathrm{E}\left({ }^{\varepsilon_{t}}\right)=0$ dan covariance $\left({ }^{\varepsilon_{t}}\right)=\Sigma$. Model koreksi kesalahan (ECM) terjadi ketika matrik $\Pi$ dibatasi. Hanya variabel $\Pi_{x_{t}}$ yang menunjukkan masih ada hubungan jangka panjang dimana masingmasing variabel tidak berubah nilainya. Dalam jangka pendek variabel $\Pi_{x_{\mathrm{t}}}$ tidak cocok dengan keseimbangan masa lalu dan sisi kiri adalah penyesuaian dari ketidakcocokannya (Gujarati, 2003).
Untuk menguji stasioneritas data dilakukan dengan uji akar unit (unit root test). Uji akar unit dapat dipandang sebagai uji stasioneritas karena pada prinsipnya uji ini dimaksudkan untuk mengamati apakah koefisien tertentu dari model autoregressive yang ditaksir mempunyai nilai satu atau tidak. Namun demikian model autoregressive memiliki distribusi yang tidak baku seperti uji $\mathrm{t}$ dan uji $\mathrm{f}$ yang tidak cukup layak dipakai guna menguji hipotesa yang dibuat. Penelitian ini menggunakan uji Dickey-Fuller (DF). Uji ini perlu karena inferensia ekonometrika biasa seperti Ordinary Least Square (OLS) dan Vector Autoregression (VAR) hanya berlaku untuk data yang bersifat stasioner.

Ada dua uji yang akan dipakai dalam penelitian ini seperti dikembangkan oleh Dickey dan Fuller (1981) (lihat Gujarati, 2003). Pengujian ini dilakukan dengan penaksiran autoregressive sebagai berikut:

$X_{t}=\alpha+\theta X_{t-1}+u_{t}$

untuk data time series diasumsikan parameter $\theta$ adalah positif. $X t$ menjadi non stasioner jika parameter $\theta$ sama dengan atau lebih dari satu. Time series pada persamaan (5) stasioner jika $\theta$ $<1$. Proses pengujiannya dilakukan dengan mengaplikasikan OLS kedalam persamaan (6) dan lihatlah hasil $\hat{\theta}$ yaitu nilai estimasi dari $\theta$. Selanjutnya dilakukan uji $\mathrm{t}(\mathrm{t}$-test) pada hipotesis nol Ho: $\theta=1$ melawan Ha: $\theta<1$. Jika s $\hat{\theta}$ merupakan standar error estimasi dari $\hat{\theta}$ maka uji statistik (t-statistic/TS) dirumuskan sebagai berikut :

$T S=\frac{\hat{\theta}-1}{s_{\hat{\theta}}}$

penolakan Ho berimplikasi pada data yang stasioner.

Dengan melakukan prosedur di atas terdapat berbagai permasalahan (Gujarati, 2003). Pertama keberadaan variabel dependen kelambanan dari persamaan (6) menandakan estimator 
Tabel 2. Nilai Kritis untuk $\mathbf{t}_{1}{ }^{*}$

\begin{tabular}{ccccccc}
\hline Nilai kritis dari $\mathbf{t}_{\mathbf{1}}$ & \multicolumn{3}{c}{ Jumlah sample $\mathbf{n}$} & \multicolumn{2}{c}{$\begin{array}{c}\text { Nilai t biasa } \\
(\mathbf{n}=\infty)\end{array}$} \\
\hline Tingkat sig 0,01 & $\mathbf{2 5}$ & $\mathbf{5 0}$ & $\mathbf{1 0 0}$ & $\mathbf{5 0 0}$ & $\boldsymbol{\infty}$ & $-2,33$ \\
Tingkat sig 0,05 & $-3,75$ & $-3,58$ & $-3,51$ & $-3,44$ & $-3,43$ & $-1,65$ \\
Tingkat sig. 0,10 & $-3,00$ & $-2,93$ & $-2,89$ & $-2,87$ & $-2,86$ & $-1,28$ \\
\hline
\end{tabular}

OLS, $\hat{\theta}$ akan bias pada sampel kecil. Hal ini bisa ditunjukkan dengan cara $\hat{\theta}$ akan bias ke bawah (biased downward). Oleh karena itu uji statistik persamaan (7) tidak dapat dipercaya dan jika tetap digunakan dapat disimpulkan bahwa $\hat{\theta}<1$ dan dikatakan bahwa $\mathrm{X}_{\mathrm{t}}$ stasioner, padahal kenyataannya tidak demikian. Kedua, jika Ho: $\theta=1$ benar dan prosesnya adalah non stasioner maka standar distribusi dengan sampel besar menjadi tidak valid (invalid). Kita tidak dapat mengandalkan uji statistik pada persamaan sebagai distribusi normal bahkan untuk sampel besar. Distribusi dari uji statistik tidak baku (standar) dan bahkan tidak simetris.

Permasalahan ini dikemukankan pertama kali oleh D.A Dickey dan W.F Fuller (lihat Dickey dan Fuller, 1979) pertama dengan menulis kembali persamaan (7) menjadi:

$\Delta X_{t}=\alpha+\theta^{*} X_{t-1}+u_{t}, \phi^{*}=\phi-1$

dengan pengujian Ho: $\phi=1$ melawan Ha: $\phi_{<1}$ dalam persamaan (6) sama dengan pengujian Ho: $\phi_{*=0}$ melawan Ha: $\phi_{*<0}$ pada persamaan (8). Pengujian terakhir sering disebut uji akar unit (unit root test).

Ahli ekonometri yang dipelopori oleh Dickey dan Fuller telah mengembangkan sebuah studi simulasi dengan menabulasi distribusi t-rasio sampel besar dengan menguji hipotesa nol (Ho) yaitu $\phi_{*=0}$. Dengan alasan adanya bias kebawah (downward biased) distribusi $\mathrm{t}$ rasio pada nol seperti jika estimator OLS $\hat{\phi}^{*}$ yang tidak bias tetapi pada nilai yang kurang dari nol (lihat Greene, 2000).
Pada situasi seperti ini yang dianggap sahih adalah $\mathrm{t}$-rasio dengan simbol $\mathrm{t}_{1}{ }^{*} \cdot \mathrm{t}_{1}{ }^{*}$ yang disebut sebagai statistic DF (Dickey Fuller statistic). Beberapa nilai kritis Dickey Fuller untuk $\mathrm{t}_{1}{ }^{*}$ ditunjukkan pada Tabel 2 yang sebagian diambil dari nilai tabel $t$ standar. Sebagai catatan bahwa untuk menolak hipotesa nol dari non stasioner, statistic $t_{1}{ }^{*}$ harus lebih negatif dari yang disarankan dengan tabel $t$ biasanya. Apabila pengujian stasioneritas menunjukkan bahwa seri data suatu peubah tidak stasioner maka harus dilihat perbedaan tingkat pertamanya (first difference) $\left(\Delta \mathrm{Y}_{\mathrm{t}}=\mathrm{Y}_{\mathrm{t}}-\mathrm{Y}_{\mathrm{t}-1}\right)$ dengan menarik diferensiasi dari peubah endogennya maka data menjadi stasioner pada kondisi 1 . Bila perbedaan tingkat pertama tidak stasioner juga, maka dilanjutkan dengan melihat perbedaan tingkat kedua, dan seterusnya sampai diperoleh kondisi stasioner. Pada akhirnya proses ini akan menghasilkan derajat integrasi dari peubah tersebut.

\section{Penentuan Lag Optimal Model VAR}

Untuk dapat melakukan estimasi model VAR maka perlu ditentukan seberapa banyak variabel lag length dibutuhkan dalam model. Di dalam model autoregresi dimana peran waktu sangat berpengaruh maka peranan lag didalam model menjadi sangat penting. Penentuan lag length juga bertujuan untuk mendapatkan model yang tepat untuk diestimasi, dimana model tersebut ditentukan oleh banyaknya jumlah lag yang digunakan (Tabel 3).

Penentuan jumlah lag dalam model VAR ditentukan pada kriteria informasi yang direkomendasikan oleh Final Prediction Error (FPE), Akaike Information Criterion (AIC), Schwarz Criterion (SC), dan Hannan-Quinn (HQ). Tanda bintang pada lag optimal menunjukkan lag optimal yang direkomendasikan oleh kriteria di 
Tabel 3. Penentuan Lag Optimal

\begin{tabular}{ll}
\hline \multicolumn{1}{c}{ Kriteria } & Rumus \\
\hline Final Prediction Error (FPE) & {$\left[\frac{R S S}{T}\right] X \frac{T+k}{T-k}$} \\
Akaike Information Criterion (AIC) & {$\left[\frac{R S S}{T}\right] X e^{(2 k / T)}$} \\
Schwarz Information Criterion (SIC) & {$\left[\frac{R S S}{T}\right] X T^{k j / T}$} \\
\hline
\end{tabular}

atas. Beberapa rumus yang biasa dipakai untuk menentukan lag optimal.

\section{Impulse Response Function dari Model VAR}

Fungsi Impulse Respon adalah untuk mengetahui pengaruh shock dalam perekonomian maka digunakan metode impulse respon function. Selama koefisien pada persamaan struktural VAR di atas sulit untuk diintepretasikan maka banyak praktisi menyarankan menggunakan impulse respon function. Fungsi impulse respon menggambarkan tingkat laju dari shock variabel yang satu terhadap variabel yang lainnya pada suatu rentang periode tertentu. Sehingga dapat dilihat lamanya pengaruh dari shock suatu variabel terhadap variabel lain sampai pengaruhnya hilang atau kembali ke titik keseimbangan. Fungsi ini akan melacak respon dari variabel tergantung apabila terdapat shock dalam $\mathbf{u}_{1}$ dan $\mathbf{u}_{2}$. Impulse response digunakan untuk melihat efek gejolak (shock) suatu standar deviasi dari variabel inovasi terhadap nilai sekarang (current time values) dan nilai yang akan datang (future values) dari variabel-variabel endogen yang terdapat dalam model yang diamati.

Impulse Response Function menggambarkan respon dari setiap variabel terhadap struktural inovasi variabel lainnya dalam model pada periode waktu bersamaan. Estimasi impulse response dapat dilihat pada saat ini dan akan datang. Selanjutnya model VAR dapat ditulis sebagai suatu vektor rata-rata bergerak atau
VMA (vector moving average). Jika dituliskan dalam bentuk matriks aljabar dari bentuk standar VAR maka akan didapat persamaan berikut:

$$
\left[\begin{array}{l}
y_{t} \\
z_{t}
\end{array}\right]=\left[\begin{array}{l}
\bar{y} \\
\bar{z}
\end{array}\right]+\sum_{i=0}^{\infty}\left[\begin{array}{ll}
a_{11} & a_{12} \\
a_{22} & a_{22}
\end{array}\right]\left[\begin{array}{l}
e_{1 t-i} \\
e_{2 t-i}
\end{array}\right]
$$

dimana $\left\{\mathrm{y}_{\mathrm{t}}\right\}$ dan $\left\{\mathrm{z}_{\mathrm{t}}\right\}$ mempunyai hubungan dengan $\left\{\mathrm{e}_{1 t}\right\}$ dan $\left\{\mathrm{e}_{2 t}\right\}$ secara berurutan. Dengan menggunakan $\left\{\varepsilon_{\mathrm{yt}}\right\}$ dan $\left\{\varepsilon_{\mathrm{zt}}\right\}$, selanjutnya dengan menggunakan operasi matriks aljabar maka vector error dapat ditentukan menjadi:

$\left[\begin{array}{l}e_{1 t} \\ e_{2 t}\end{array}\right]=\left[1 /\left(1-b_{12} b_{21}\right)\right]\left[\begin{array}{cc}1 & -b_{12} \\ -b_{21} & 1\end{array}\right]\left[\begin{array}{l}\varepsilon_{y t} \\ \varepsilon_{z t}\end{array}\right]$

Moving average representation dalam persamaan (9) dan (10) dapat ditulis dengan kaitan $\left\{\varepsilon_{y t}\right\}$ dan $\left\{\varepsilon_{\mathrm{zt}}\right\}$ secara berulang menjadi:

$$
\left[\begin{array}{l}
y_{t} \\
z_{t}
\end{array}\right]=\left[\begin{array}{l}
\bar{y} \\
\bar{z}
\end{array}\right]+\sum_{i=0}^{\infty}\left[\begin{array}{ll}
\Phi_{11}(i) & \Phi_{12}(i) \\
\Phi_{21}(i) & \Phi_{22}(i)
\end{array}\right]\left[\begin{array}{l}
\varepsilon_{y t-i} \\
\varepsilon_{z t-1}
\end{array}\right]
$$

Empat satuan koefisien $\Phi_{11}(\mathrm{i}), \Phi_{12}(\mathrm{i}), \Phi_{21}(\mathrm{i})$, dan $\Phi_{22}(\mathrm{i})$ inilah yang disebut dengan impulse response function (IRF).

dimana: $\Phi_{\mathrm{ij}}(i)$ adalah efek dari struktural shock pada y dan $\mathrm{z} ; \Phi_{\mathrm{ij}}(0)$ adalah impact multipliers; $\Sigma \Phi_{i j}(i)$ adalah cumulative multipliers.

$\Sigma \Phi_{i j}(i)=$ pada saat $\mathrm{n} \rightarrow \infty=$ long run multipliers 


\section{Variance Decomposition dari Siklus Bisnis}

The Cholesky Decomposition atau biasa disebut juga dengan the variance decomposition memberikan informasi mengenai variabel inovasi yang relatif lebih penting dalam VAR. Pada dasarnya test ini merupakan metode lain untuk menggambarkan sistem dinamis yang terdapat dalam VAR. Test ini digunakan untuk menyusun perkiraan error variance suatu variabel, yaitu seberapa besar perbedaan antara variance sebelum dan sesudah shock, baik shock yang berasal dari diri sendiri maupun shock dari variabel lain.

Variance decompotition akan memberikan informasi mengenai proporsi dari pergerakan pengaruh shock pada sebuah variabel terhadap shock variabel yang lain pada periode saat ini dan periode yang akan datang. Variance decomposition memisahkan variasi perubahan shock dari setiap variabel terhadap variabel lain dalam model. Setiap variabel perubahan dalam model diasumsikan tidak berkorelasi. Variance decomposition menggambarkan besarnya sumbangan pengaruh dari suatu variabel perubahan terhadap variabel lain dalam model. Bentuk $V M A$ dari variabel $\mathrm{x}$ pada satu periode didepan di tuliskan sebagai berikut:

$$
X_{t+1}=\bar{X}+\sum_{i=0}^{\infty} \Phi_{i} \varepsilon_{t+1-i}
$$

Forecast error pada satu periode ke depan adalah :

$$
e_{t} X_{t+1}=\bar{X}+\sum_{i=0}^{\infty} \Phi_{i} \varepsilon_{t+1-i}
$$

Peramalan satu periode kedepan dilambangkan dengan $\varphi_{0} \varepsilon \mathrm{t}_{\mathrm{t}+1}$. Forecast error pada periode $\mathrm{n}$ ke depan adalah:

$$
X_{t+n}-e_{t} X_{t+1}=\bar{X}+\sum_{i=0}^{\infty} \Phi_{i} \varepsilon_{t+1-i}
$$

Forecast error pada $\mathrm{n}$ periode ke depan untuk variabel y adalah:

$$
\begin{aligned}
\mathrm{Y}_{\mathrm{t}+\mathrm{n}}-\mathrm{e}_{\mathrm{t}} \mathrm{y}_{\mathrm{t}+\mathrm{n}}= & \varphi_{11}(0) \varepsilon_{\mathrm{yt}+\mathrm{n}}+\varphi_{11}(1) \varepsilon_{\mathrm{yt}+\mathrm{n}-1}+\ldots+ \\
& \varphi_{11}(\mathrm{n}-1) \varepsilon_{\mathrm{yt}+1}
\end{aligned}
$$

$\varphi_{12}(0) \varepsilon_{\mathrm{zt}+\mathrm{n}}+\varphi_{12}(1) \varepsilon_{\mathrm{zt}+\mathrm{n}-1}+\ldots+$

$\varphi_{12}(\mathrm{n}-1) \varepsilon_{\mathrm{zt}+1}$

Variance dari forecast error $\mathrm{Y}_{\mathrm{t}+\mathrm{n}}$ periode $\mathrm{n}$ ke depan adalah $\sigma_{\mathrm{y}}(\mathrm{n})^{2}$, dimana:

$$
\begin{aligned}
\sigma_{\mathrm{y}}(\mathrm{n})^{2}= & \sigma_{\mathrm{y}}^{2}\left[\varphi_{11}(0)^{2}+\varphi_{11}(1)^{2}+\ldots+\varphi_{11}(\mathrm{n}-1)^{2}\right]+ \\
& \sigma^{2}\left[\varphi_{12}(0)^{2}+\varphi_{12}(1)^{2}+\ldots+\varphi_{12}(\mathrm{n}-1)^{2}\right]
\end{aligned}
$$

Forecast error variance decomposition adalah proporsi dari $\sigma_{\mathrm{y}}(\mathrm{n})^{2}$ terhadap shock y dan shock $\mathrm{z}$. Sehingga forecast error variance decomposition pada shock y adalah:

$\sigma^{2}\left[\varphi_{11}(0)^{2}+\varphi_{11}(1)^{2}+\ldots+\varphi_{11}(\mathrm{n}-1)^{2}\right] / \sigma_{\mathrm{y}}(\mathrm{n})^{2}$

Sementara itu forecast error variance decomposition pada shock $\mathrm{z}$ adalah :

$\sigma^{2} z\left[\varphi_{11}(0)^{2}+\varphi_{11}(1)^{2}+\ldots+\varphi_{11}(n-1)^{2}\right] / \sigma_{y}(n)^{2}$

\section{Hipotesis Penelitian}

Meningkatnya intensitas perdagangan akan mendorong meningkatnya permintaan dan penawaran barang antarnegara yang pada gilirannya akan meningkatkan keterkaitan hubungan antarnegara. Akibatnya perekonomian akan semakin konvergen dan korelasi siklus bisnisnya menjadi lebih selaras. Pendapat ini didukung oleh kajian yang sudah dilakukan oleh Shin dan Wang (2004) serta Rana (2007). Dengan proposisi tersebut maka dapat dikemukakan hipotesis 1: intensitas perdagangan memiliki pengaruh positif terhadap keselarasan siklus bisnis.

Meningkatnya perdagangan internasional akan memerlukan beberapa koordinasi kebijakan, salah satunya adalah koordinasi kebijakan fiskal. Adanya koordinasi kebijakan fiskal akan menyebabkan shock kebijakan fiskal tersebut akan menjadi relatif sama antarnegara sehingga siklus bisnisnya menjadi lebih selaras (Frankel dan Rose, 1998). Berdasarkan proposisi tersebut maka dapat dikemukakan hipotesis 3: koordinasi kebijakan fiskal memiliki pengaruh positif terhadap keselarasan siklus bisnis.

Semakin terintegrasi perekonomian suatu negara maka akan memerlukan koordinasi ke- 
bijakan moneter karena masing-masing negara memiliki kebijakan dan sistim moneter yang berbeda-beda. Bagi negara yang sudah terintegrasi, beberapa kesepakatan bidang moneter dibuat untuk memudahkan dalam melakukan kerjasama terutama bidang perdagangan. Semakin meningkat koordinasi kebijakan moneter pada negara yang terintegrasi perdagangannya maka akan semakin selaras siklus bisnisnya. Pernyataan ini didukung oleh kajian yang sudah dilakukan oleh Shin dan Wang (2004) dan Rana (2007). Proposisi ini mendasari hipotesis 4: koordinasi kebijakan moneter memiliki pengaruh positif terhadap keselarasan siklus bisnis.

\section{HASIL DAN PEMBAHASAN}

\section{Pengujian Data Panel}

Dari hasil perhitungan data panel yang disajikan pada Tabel 4 menggunakan metode Seemingly Unrelated Regression/SUR memperlihatkan bahwa intensitas perdagangan memberikan pengaruh yang positif dan signifikan terhadap keselarasan siklus bisnis pada level kepercayaan satu persen, artinya meningkatnya intensitas perdagangan akan semakin meningkatkan keselarasan siklus bisnis. Hasil ini sesuai dengan hipotesis yang menyatakan bahwa semakin meningkat intensitas perdagangan maka akan berpengaruh positif terhadap keselarasan siklus bisnisnya. Temuan ini mendukung argumentasi Rana (2007) serta Shin dan Wang (2004) yang menyatakan semakin banyak negara melakukan intensitas dengan negara lain maka akan berdampak terhadap kesamaan pergerakan siklus bisnis. Argumentasi ini diperkuat oleh data statistik yang menyatakan bahwa intensitas perdagangan keenam negara dalam sampel menunjukkan trend yang terus meningkat. Keberadaan ASEAN-4 sebagai mitra dagang negara Uni Eropa (dalam hal ini Jerman dan Belanda) sangat penting terutama untuk peningkatan kerjasama perdagangan antara ASEAN secara umumnya dengan Uni Eropa (www.asean.org).

Hasil perhitungan untuk variabel koordinasi kebijakan moneter memberikan pengaruh yang positif dan signifikan terhadap keselarasan siklus bisnis pada level kepercayaan satu persen. Temuan ini sesuai dengan hipotesis yang dikemukakan bahwa bahwa semakin meningkat intensitas perdagangan akan memerlukan berbagai koordinasi kebijakan terutama koordinasi kebijakan moneter. Kenyataannya beberapa kesepakatan kerjasama di bidang moneter sudah diterapkan di ASEAN. Menteri Keuangan ASEAN telah menandatangani $\mathrm{Mi}$ nisterial Understanding on ASEAN Cooperation in Finance di Thailand tahun 1997. Ministerial Understanding tersebut menjadi kerangka peningkatan kerjasama di bidang keuangan yang mencakup keuangan dan perbankan, pasar uang dan modal, masalah-masalah pabean, asuransi, perpajakan dan pengembangan SDM di sektor keuangan. Para Menteri juga telah menandatangani ASEAN Agreement on Customs yang bertujuan untuk membantu mempercepat realisasi AFTA karena mencakup aturan-aturan yang memfasilitasi perdagangan intra-ASEAN dan arus investasi. Semakin tinggi tingkat koordinasi kebijakan moneter yang disepakati maka akan cenderung meningkatkan keselarasan siklus bisnisnya. Hasil ini sesuai dengan kajian yang sudah dilakukan Rana (2007) serta

Tabel 4. Hasil Perhitungan Regresi dengan Metode SUR

\begin{tabular}{|c|c|c|}
\hline \multirow{2}{*}{ Variabel } & \multicolumn{2}{|c|}{ Seemingly Unrelated Regression } \\
\hline & Koefisien & t-statistik \\
\hline TI & 70,94167 & $(52.31783)^{*}$ \\
\hline MON & 0,202863 & $(8,067341)^{*}$ \\
\hline FIS & $-0,108964$ & $(-3,487150)^{*}$ \\
\hline Observation & & 174 \\
\hline R-Squared & & -30.196371 \\
\hline
\end{tabular}

Sumber: data di olah

Catatan: * signifikan pada level 1 persen; ** signifikan pada level 5 persen; ${ }^{* * *}$ signifikan pada level 10 persen. 
Teng dan Way (2005).

Temuan yang berbeda terdapat pada variabel koordinasi kebijakan fiskal. Hasil perhitungan menyatakan bahwa koordinasi kebijakan fiskal memberikan hasil yang negatif dan signifikan terhadap keselarasan siklus bisnis. Hasil ini tidak sesuai dengan hipotesis yang menyatakan bahwa semakin meningkatnya integrasi perdagangan akan membutuhkan lebih banyak koordinasi kebijakan fiskal. Indikasi ini memperkuat argumentasi yang menyatakan bahwa semakin tinggi defisit anggaran akan berdampak semakin rentannya sebuah perekonomian. Berbagai upaya dilakukan untuk menutup defisit, di antaranya meningkatkan produksi domestiknya. Selama ini penanganan kebijakan fiskal bersifat divergen dan disesuaikan dengan perekonomian negara masing-masing. Hasil negatif ini relevan dengan kajian yang sudah dilakukan oleh Shin dan wang (2005).

Ketidakselarasan siklus bisnis ini antara lain disebabkan oleh perbedaan dalam penanganan masalah kebijakan fiskal. Penerapan kebijakan fiskal pada tiap negara bersifat internal dan cenderung divergen. Penanganan masalah defisit anggaran disesuaikan dengan struktur perekonomiannya masing-masing. Karena memiliki sifat internal maka sejauh ini koordinasi kebijakan fiskal belum dilakukan secara intensif.
Semakin tinggi defisit anggaran pemerintah, akan berdampak semakin rentannya sebuah perekonomian. Berbagai upaya dilakukan untuk menutup defisit, di antaranya adalah reformasi perpajakan, melalui utang luar negeri dan meningkatkan produksi domestiknya. Tujuannya adalah meningkatkan produksi nasional dan pertumbuhan ekonomi, memperluas lapangan kerja, mengurangi pengangguran dan mengatasi inflasi (Suparmoko, 2000).

Salah satu upaya yang sudah dilakukan untuk mengatasi masalah defisit antara lain melalui pemberian stimulus fiskal. Gambar 1 memperlihatkan pemberian stimulus fiskal di beberapa negara. Kelompok G-20 memberikan stimulus fiskal kepada negara-negara yang mengalami defisit anggaran pada fase pertama pada tahun 2009 sebanyak 1,4 trilyun dolar (www.fiskal.depkeu.go.id). Pada negara berkembang seperti Indonesia yang mengalami defisit anggaran 2,5 persen diberikan stimulus fiskal sebesar 1,4 persen, sedangkan untuk negara maju seperti Jepang yang mengalami defisit anggaran 7,1 persen diberikan stimulus fiskal sebesar 3,1 persen.

Faktor lain yang juga menurunkan keselarasan siklus bisnis adalah krisis ekonomi yang terjadi pada tahun 1997 yang berakibat membesarnya defisit transaksi berjalan pada neraca pembayaran, serta menurunnya daya saing eks-

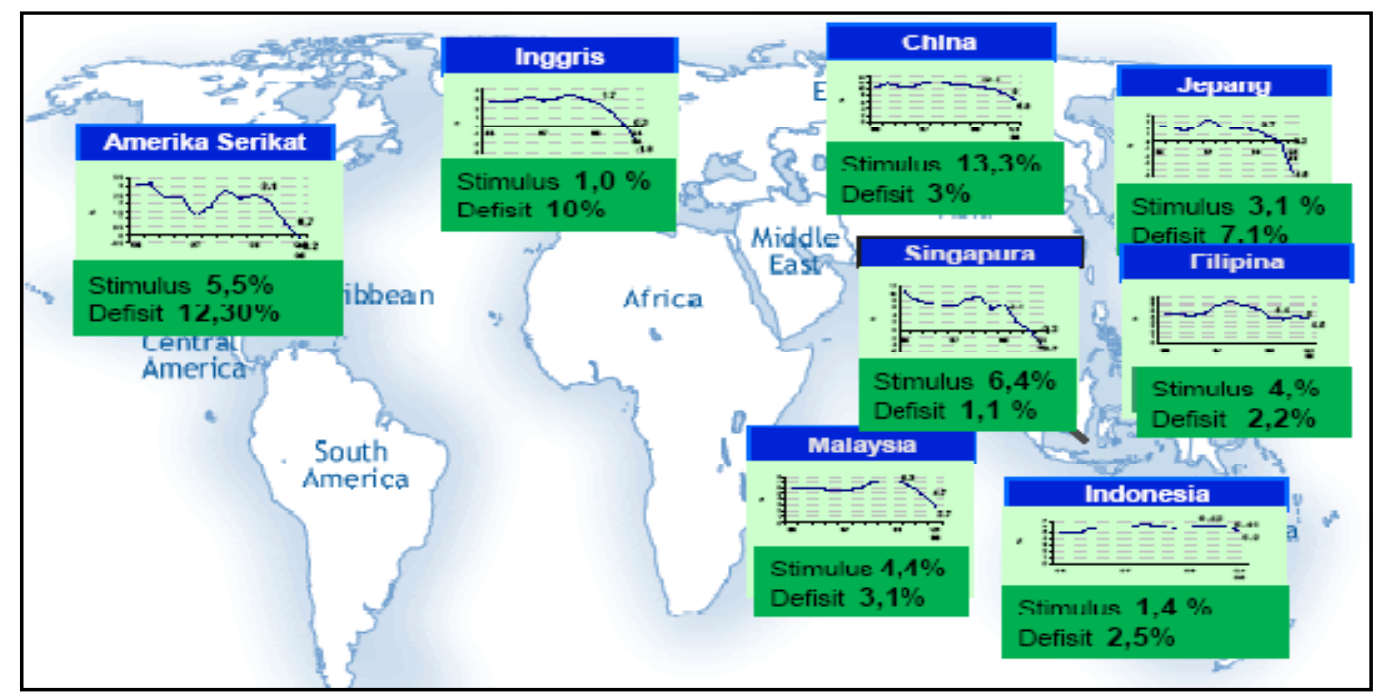

Sumber: www.fiskal.depkeu.go.id

Gambar 1. Program Stimulus Fiskal di Beberapa Negara 
por negara-negara di Asia Tenggara. Menurunnya daya saing ekpor memang berkaitan dengan nilai mata uang yang cenderung overvalued dan hal ini terutama menimpa Baht Thailand yang selama bertahun-tahun, nilainya tetap terhadap dolar AS. Hasil negatif ini serupa dengan penelitian yang dilakukan Teng dan Way (2005) yang juga menemukan bahwa koordinasi kebijakan fiskal pada ASEAN-5 serta India dan China cenderung menurunkan siklus bisnis.

\section{Hasil Pengujian Akar Unit}

Dari hasil perhitungan uji akar unit dapat dilihat bahwa secara keseluruhan semua variabel sudah stasioner (lihat Tabel 5). Dalam uji ini hanya variabel kurs yang tidak lolos uji akar unit sehingga harus diteruskan dengan uji derajat integrasi satu. Hal ini menunjukkan ada masalah dengan akar unit yang menggambarkan situasi non stasioner. Untuk selanjutnya perlu dilakukan uji derajat integrasi untuk mengetahui pada derajat ke berapa data-data tersebut stasioner.

Secara umum hasil pengujian terlihat bahwa variabel BC sudah lolos uji akar unit sehingga tidak perlu diteruskan dengan uji derajat integrasi. Pada negara Malaysia, Thailand, dan Jerman sudah stasioner pada derajat kepercayaan satu persen, sedangkan Belanda stasioner pada derajat kepercayaan lima persen. Sementara itu Indonesia dan Filipina stasioner pada derajat kepercayaan sepuluh persen.

Pada pengujian variabel intensitas perdagangan hanya Belanda yang sudah lolos pada uji akar unit, sedangkan lima negara lainnya tidak lolos sehingga harus dilakukan uji derajat integrasi 1. Pada Jerman, Malaysia dan Indonesia sudah stasioner pada derajat kepercayaan satu persen, namun untuk Thailand dan Filipina stasioner pada derajat kepercayaan sepuluh persen. Perhitungan pada variabel koordinasi kebijakan moneter memperlihatkan bahwa

Tabel 5. Uji Akar Unit dan Uji Derajat Integrasi I

\begin{tabular}{|c|c|c|c|}
\hline Negara & Variabel & Uji Akar Unit & Derajat Integrasi 1 \\
\hline \multirow[t]{4}{*}{ Indonesia } & $\mathrm{BC}$ & $3,584677^{* *}$ & \\
\hline & $\mathrm{TI}$ & 0,567722 & $-5,733068^{*}$ \\
\hline & MPC & $-2,638936$ & $-3,456246^{* *}$ \\
\hline & FPC & $-4,275077^{*}$ & \\
\hline \multirow{4}{*}{ Malaysia } & $\mathrm{BC}$ & $-3,898484$ & \\
\hline & $\mathrm{TI}$ & $-0,795151$ & $-4,825984^{*}$ \\
\hline & MPC & $-2,479869$ & $-5,213031^{*}$ \\
\hline & FPC & $-2,280551$ & $-4,420069^{*}$ \\
\hline \multirow[t]{4}{*}{ Filipina } & $\mathrm{BC}$ & $-3,185213^{* *}$ & \\
\hline & $\mathrm{TI}$ & $-1,378927$ & $-2,860993^{* * *}$ \\
\hline & $\mathrm{MPC}$ & $-2,620286$ & $-4,662211^{*}$ \\
\hline & FPC & $-3,042284^{* *}$ & \\
\hline \multirow[t]{4}{*}{ Thailand } & $\mathrm{BC}$ & $-3,555491$ & \\
\hline & TI & $-0,104350$ & $-2,780867^{* * *}$ \\
\hline & MPC & $-1,363675$ & $-4,518456^{*}$ \\
\hline & FPC & $-1,953676$ & $-4,479065^{*}$ \\
\hline \multirow[t]{4}{*}{ Jerman } & $\mathrm{BC}$ & $-3,830016$ & \\
\hline & $\mathrm{TI}$ & $-1,376398$ & $-4,984260^{*}$ \\
\hline & MPC & $-2,484451$ & $-5,266130^{*}$ \\
\hline & FPC & $-2,938832^{* * *}$ & \\
\hline \multirow[t]{4}{*}{ Belanda } & $\mathrm{BC}$ & $-6,316442^{*}$ & \\
\hline & TI & $-2,895523^{* * *}$ & \\
\hline & MPC & $-2,560670$ & $3,655497^{* *}$ \\
\hline & FPC & $-3,712854$ & \\
\hline
\end{tabular}

Sumber: data di olah

Catatan: * signifikan pada level 1 persen; ** signifikan pada level 5 persen; *** signifikan pada level 10 persen. 


\section{Pengujian Vector Autoregression}

Penentuan lag length juga bertujuan untuk mendapatkan model yang tepat untuk diestimasi, dimana model tersebut ditentukan oleh banyaknya jumlah lag yang digunakan. Hasil dari uji kelambanan optimal VAR disajikan pada

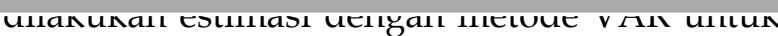
melihat estimasi jangka panjangnya. Hasil estimasi model VAR selengkapnya disajikan pada Tabel 7. Dari hasil perhitungan secara keseluruhan diketahui bahwa seluruh variabel memiliki nilai koefisien determinasi antara 27 persen sampai 94 persen, artinya sebanyak lebih dari

Tabel 6. Hasil Uji Kelambanan

\begin{tabular}{|c|c|c|c|c|c|c|}
\hline \multicolumn{7}{|l|}{ INDONESIA } \\
\hline Lag & $\log L$ & LR & FPE & AIC & SC & HQ \\
\hline 0 & 198,8272 & NA & $6,35 \mathrm{E}-12$ & $-14,43164$ & $-14,23967$ & $-14,37456$ \\
\hline 1 & 261,8700 & $102,7365^{*}$ & $1,98 \mathrm{E}-13$ & $-17,91630$ & $-16,95642^{*}$ & $-17,63088^{*}$ \\
\hline 2 & 279,2940 & 23,23203 & $1,95 \mathrm{E}-13^{*}$ & $-18,02178^{*}$ & $-16,29400$ & $-17,50802$ \\
\hline \multicolumn{7}{|l|}{ MALAYSIA } \\
\hline 0 & 139,5009 & NA & 5,14E-10 & $-10,03710$ & $-9,845127$ & $-9,980018$ \\
\hline 1 & 210,5709 & 115,8178 & $8,85 \mathrm{E}-12$ & $-14,11636$ & $-13,15648^{*}$ & $-13,83094$ \\
\hline 2 & 231,5468 & $27,96795^{*}$ & $6,69 \mathrm{E}-12^{*}$ & $-14,48495^{*}$ & $-12,75717$ & $-13,97119^{*}$ \\
\hline \multicolumn{7}{|l|}{ THAILAND } \\
\hline 0 & 147,0656 & NA & 2,94E-10 & $-10,59745$ & $-10,40547$ & $-10,54036$ \\
\hline 1 & 223,7433 & $124,9563^{*}$ & $3,34 \mathrm{E}-12^{*}$ & $-15,09210^{*}$ & $-14,13222^{*}$ & $-14,80667^{*}$ \\
\hline 2 & 233,4780 & 12,97967 & 5,80E-12 & $-14,62800$ & $-12,90022$ & $-14,11424$ \\
\hline \multicolumn{7}{|l|}{ FILIPINA } \\
\hline 0 & 180,4862 & NA & 2,47E-11 & $-13,07305$ & $-12,88108$ & $-13,01597$ \\
\hline 1 & 255,5546 & 122,3336 & $3,16 \mathrm{E}-13$ & $-17,44849$ & $-16,48861^{*}$ & $-17,16306$ \\
\hline 2 & 279,3225 & $31,69064^{*}$ & $1,94 \mathrm{E}-13^{*}$ & $-18,02389^{*}$ & $-16,29611$ & $-17,51013^{*}$ \\
\hline \multicolumn{7}{|l|}{ JERMAN } \\
\hline 0 & 184,3345 & NA & $1,86 \mathrm{E}-11$ & $-13,35811$ & $-13,16613$ & $-13,30102$ \\
\hline 1 & 246,3077 & $100,9935^{*}$ & $6,27 \mathrm{E}-13^{*}$ & $-16,76353^{*}$ & $-15,80366^{*}$ & $-16,47811^{*}$ \\
\hline 2 & 261,5075 & 20,26644 & 7,27E-13 & $-16,70426$ & $-14,97648$ & $-16,19050$ \\
\hline \multicolumn{7}{|l|}{ BELANDA } \\
\hline 0 & 203,6485 & NA & 4,44E-12 & $-14,78878$ & $-14,59680$ & $-14,73169$ \\
\hline 1 & 238,2789 & $56,43468^{*}$ & $1,14 \mathrm{E}-12^{*}$ & $-16,16881^{*}$ & $-15,20893^{*}$ & $-15,88338^{*}$ \\
\hline 2 & 250,6532 & 16,49911 & $1,62 \mathrm{E}-12$ & $-15,90024$ & $-14,17245$ & $-15,38648$ \\
\hline
\end{tabular}


Tabel 7. Hasil Perhitungan VAR

\begin{tabular}{lcccc}
\hline & BC & TI & FIS & MON \\
\hline Indonesia & 0,606575 & 0,939548 & 0,454268 & 0,606383 \\
Malaysia & 0,931956 & 0,609539 & 0,582918 & 0,776413 \\
Filipina & 0,875046 & 0,611557 & 0,889336 & 0,825451 \\
Thailand & 0,949711 & 0,712784 & 0,581268 & 0,720834 \\
Jerman & 0,420398 & 0,386566 & 0,673159 & 0,903781 \\
Belanda & 0,279261 & 0,289638 & 0,564260 & 0,726557 \\
\hline
\end{tabular}

Sumber: data diolah

27 persen variasi variabel independen mampu menjelaskan variabel dependennya. Hasil perhitungan terendah diperoleh negara Belanda karena hanya memiliki koefisien determinasi 27 persen, artinya hanya 27 persen dari variabel independen mampu menjelaskan variabel dependennya.
Sementara itu pengujian parsial dengan uji-t untuk Indonesia dan Malaysia diketahui masing-masing memiliki enam hubungan antar variabel yang lolos uji-t (lihat Tabel 8). Dipandang dari sudut kecepatan variabel yang mempengaruhi variabel dependen sendiri maka variabel koordinasi kebijakan fiskal, BC, inten-

Tabel 8. Hubungan Variabel Dependen dan Independen

\begin{tabular}{|c|c|c|}
\hline \multirow{2}{*}{ Negara } & \multicolumn{2}{|c|}{ Kecepatan Mempengaruhi } \\
\hline & Dengan Lag Variabel Sendiri & Dengan Lag Variabel Lain \\
\hline Indonesia & $\begin{array}{l}\text { FPC_INA(-1) } \rightarrow \text { FPC INA } \\
\text { MPC_INA(-1) } \rightarrow \text { MPC_INA } \\
\text { TI_INA(-1) } \rightarrow \text { TI_INA } \\
\text { BC_INA(-1) } \rightarrow \text { BC_INA }\end{array}$ & $\begin{array}{l}\text { FPC_INA(-1) } \rightarrow \text {-BC_INA } \\
\text { MPC_INA }(-1) \rightarrow \text { BC_INA }\end{array}$ \\
\hline Malaysia & $\begin{array}{l}\text { FPC_MAS }(-1) \rightarrow \text { FPC MAS } \\
\text { FPC_MAS }(-2) \rightarrow \text { FPC MAS } \\
\text { BC_MAS }(-1) \rightarrow \text { BC_MAS } \\
\text { MPC_MAS(-1) } \rightarrow \text { MPC_MAS } \\
\text { TI_MAS(-1) } \rightarrow \text { TI_MAS }\end{array}$ & FPC_MAS(-1) $\rightarrow$ BC_M \\
\hline Filipina & $\begin{array}{l}\text { FPC_PHIL(-1) } \rightarrow \text { FPC_PHIL } \\
\text { FPC_PHIL }(-2) \rightarrow \text {-FPC_PHIL } \\
\text { BC_PHIL(-1) } \rightarrow \text { BC_PHIL } \\
\text { MPC_PHIL(-1) } \rightarrow \text { MPC_PHIL } \\
\text { TI_PHIL(-1) } \rightarrow \text { TI_PHIL }\end{array}$ & $\begin{array}{l}\text { FPC_PHIL(-1) } \rightarrow \text {-BC_PHIL } \\
\text { BC_PHIL(-2) } \rightarrow \text { FPC_PHIL } \\
\text { MPC_PHIL(-1) } \rightarrow \text {-TI_PHIL } \\
\text { MPC_PHIL(-2) } \rightarrow \text { FPC_PHIL } \\
\text { MPC_PHIL(-2) } \rightarrow \text { BC_PHIL } \\
\text { TI_PHIL(-1) } \rightarrow \text {-FPC_PHIL } \\
\text { TI_PHIL(-2) } \rightarrow \text { FPC_PHIL }\end{array}$ \\
\hline Thailand & $\begin{array}{l}\text { FPC_THA }(-1) \rightarrow \text { FPC_THA } \\
\text { BC_THA }(-1) \rightarrow \text { BC_THA } \\
\text { MPC_THA }(-1) \rightarrow \text { MPC_THA }\end{array}$ & $\begin{array}{l}\text { FPC_THA }(-1) \rightarrow \text { BC_THA } \\
\text { BC_THA }(-1) \rightarrow \text { - MPC_THA } \\
\text { MPC_THA(-1) } \rightarrow \text { BC_THA } \\
\text { TI_THA(-1) } \rightarrow \text { BC_THA } \\
\text { TI_THA(-1) } \rightarrow->\text {-MPC_THA }\end{array}$ \\
\hline Jerman & $\begin{array}{l}\text { BC_JRM(-1) } \rightarrow \text { BC_JRM } \\
\text { TI_JRM }(-1) \rightarrow \text { TI_JRM } \\
\text { FPC_JRM }(-1) \rightarrow \text { FPC_JRM } \\
\text { MPC_JRM }(-1) \rightarrow \text { MPC_JRM }\end{array}$ & $\begin{array}{l}\text { TI_JRM }(-1) \rightarrow \text {-BC_JRM } \\
\text { FPC_JRM }(-1) \rightarrow \text { BC_JRM } \\
\text { MPC_JRM }(-1) \rightarrow \text { BC_JRM } \\
\text { MPC_JRM }(-1) \rightarrow \text { TI_JRM }\end{array}$ \\
\hline Belanda & $\begin{array}{l}\text { BC_BLD(-1) } \rightarrow \text { BC_BLD } \\
\text { MPC_BLD }(-1) \rightarrow \text { MPC_BLD } \\
\text { TI_BLD }(-1) \rightarrow \text { TI_BLD } \\
\text { FPC_BLD(-1) } \rightarrow \text { FPC_BLD }\end{array}$ & $\begin{array}{l}\text { BC_BLD }(-1) \rightarrow-M P C \_B L D ; \\
\text { FPC_BLD }(-1) \rightarrow \text { BC_BLD }\end{array}$ \\
\hline
\end{tabular}

Catatan: tanda (-) menunjukkan hubungan yang negatif 
sitas perdagangan dan koordinasi kebijakan moneter konsisten pada lag 1, sedangkan jika dilihat dari kecepatan variabel dalam mempengaruhi variabel lain maka variabel koordinasi kebijakan fiskal dan moneter akan mempengaruhi variabel BC. Dari hasil tersebut tidak ditemukan hubungan kausalitas dua arah di antara keempat variabel tersebut.

Hasil yang sedikit berbeda terdapat pada pengujian untuk Filipina. Pengujian parsial dengan uji-t untuk Filipina diketahui memiliki dua belas hubungan antarvariabel yang lolos uji-t. Dipandang dari sudut kecepatan mempengaruhi antarvariabel kelambanan terhadap variabel dependen sendiri maka variabel koordinasi kebijakan fiskal konsisten pada lag 1 dan 2 , sedangkan untuk variabel $B C$, intensitas perdagangan dan koordinasi kebijakan moneter konsisten pada lag 1 . Hubungan kausalitas dua arah ditunjukkan oleh hubungan antarvariabel koordinasi kebijakan fiskal dan siklus bisnis. man dan Belanda, masing-masing diketahui memiliki delapan dan enam hubungan antar variabel yang lolos uji-t. Apabila dilihat dari sudut kecepatan mempengaruhi antar variabel kelambanan terhadap variabel dependen sendiri maka variabel koordinasi kebijakan fiskal, kebijakan moneter, intensitas perdagangan dan BC konsisten pada lag 1. Pada Jerman, hubungan kausalitas dua arah ditunjukkan oleh hubungan antarvariabel koordinasi kebijakan moneter dan siklus bisnis sedangkan di Belanda tidak ditemukan hubungan kausalitas dua arah di antara kelima variabel tersebut.

\section{Hasil Pengujian Impulse Responses}

Impulse Response Function menggambarkan respon dari setiap variabel terhadap struktural inovasi variabel lainnya dalam model pada periode waktu bersamaan. Estimasi impulse response dapat dilihat pada masa sekarang dan di waktu yang akan datang. Pengujian impulse response tunjukkan oleh hubungan antarvariabel koordinasi kebijakan moneter dan siklus bisnis

Pengujian parsial dengan uji-t untuk Jer-
Pengujian variabel GDP terhadap koordinasi kebijakan moneter adalah ketika ada shock dari kenaikan koordinasi kebijakan moneter

Response to Cholesky One S.D. Innovations \pm 2 S.E.

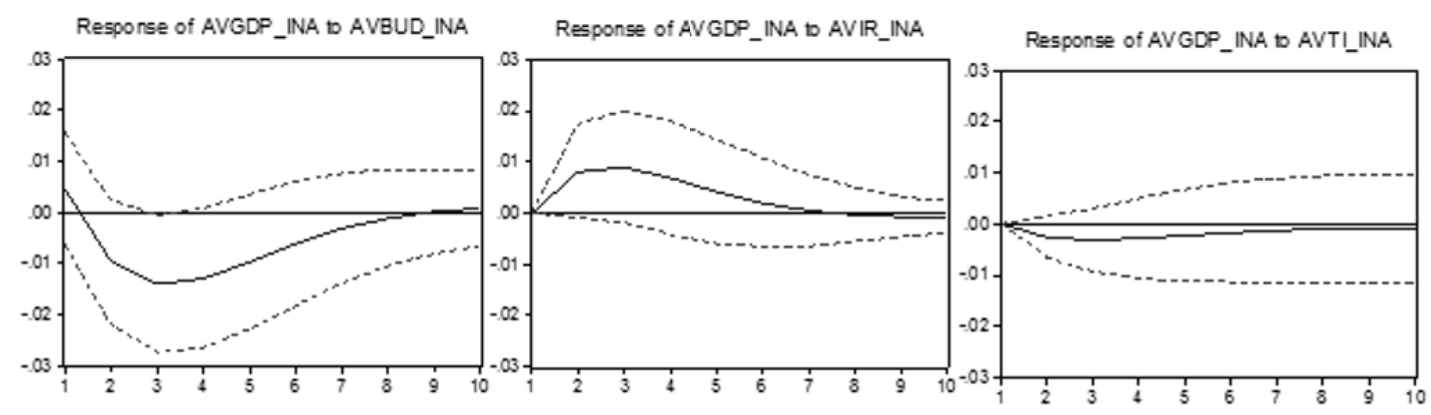

Gambar 2. Impulse Response Indonesia 
Response to Cholesky One S.D. Innovations \pm 2 S.E.
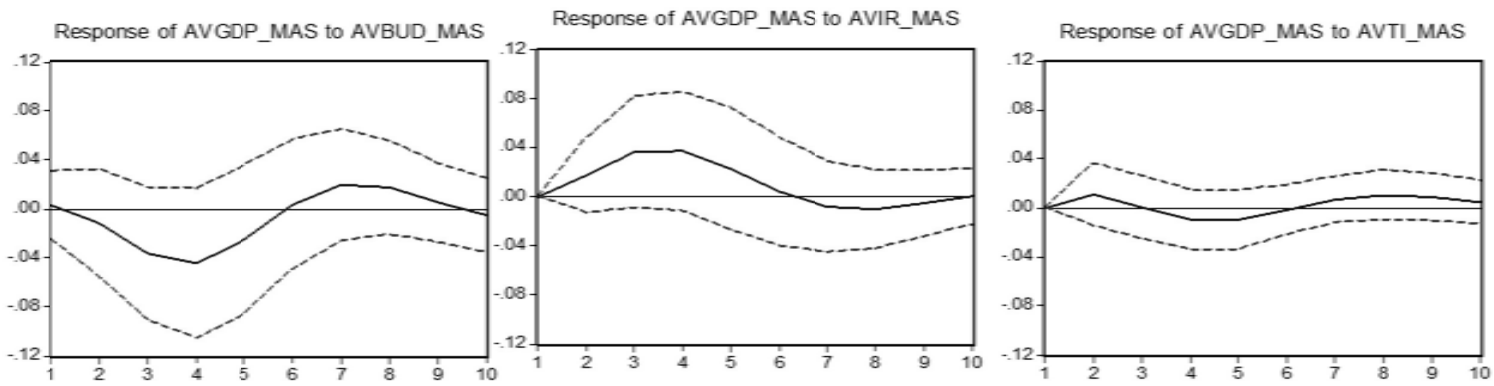

Gambar 3. Impulse Response Malaysia

maka dampaknya terhadap GDP mula-mula mengalami kenaikan dan mencapai puncaknya pada periode ke 3 dan selanjutnya mengalami penurunan sampai periode ke 10. Dilihat dari respon variabel GDP terhadap variabel intensitas perdagangan maka adalah ketika ada shock dari kenaikan intensitas perdagangan maka dampaknya terhadap GDP mula-mula mengalami kenaikan dan mencapai kestabilan pada periode ke 6 namun tidak sampai mengalami keseimbangan.

Pengujian impulse response untuk Malaysia dapat dilihat pada Gambar 3. Apabila dilihat dari respon variabel GDP terhadap koordinasi

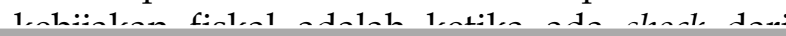

mengalami kenaikan sampai titik puncaknya pada periode ke 2 selanjutnya turun sampai periode ke 5 dan meningkat kembali sampai pada periode ke 7 dan selanjutnya bergerak stabil namun tidak sampai mengalami keseimbangan.

Pengujian impulse response untuk Filipina dapat dilihat pada Gambar 4. Apabila dilihat dari respon variabel GDP terhadap koordinasi kebijakan fiskal maka ketika ada shock dari kenaikan koordinasi kebijakan fiskal maka dampaknya terhadap GDP mula-mula mengalami penurunan signifikan dan mencapai titik terendah pada periode ke 3 kemudian naik respon variabel GDP terhadap variabel intensitas perdagangan memperlihatkan bahwa ketika ada shock dari kenaikan intensitas perdagangan maka dampaknya terhadap GDP mula-mula
GDP mula-mula mengalami kenaikan sampai periode ke 2 dan selanjutnya mengalami penurunan sampai titik puncaknya pada periode ke 3 selanjutnya meningkat lagi sampai periode ke 
Response to Cholesky One S.D. Innovations \pm 2 S.E
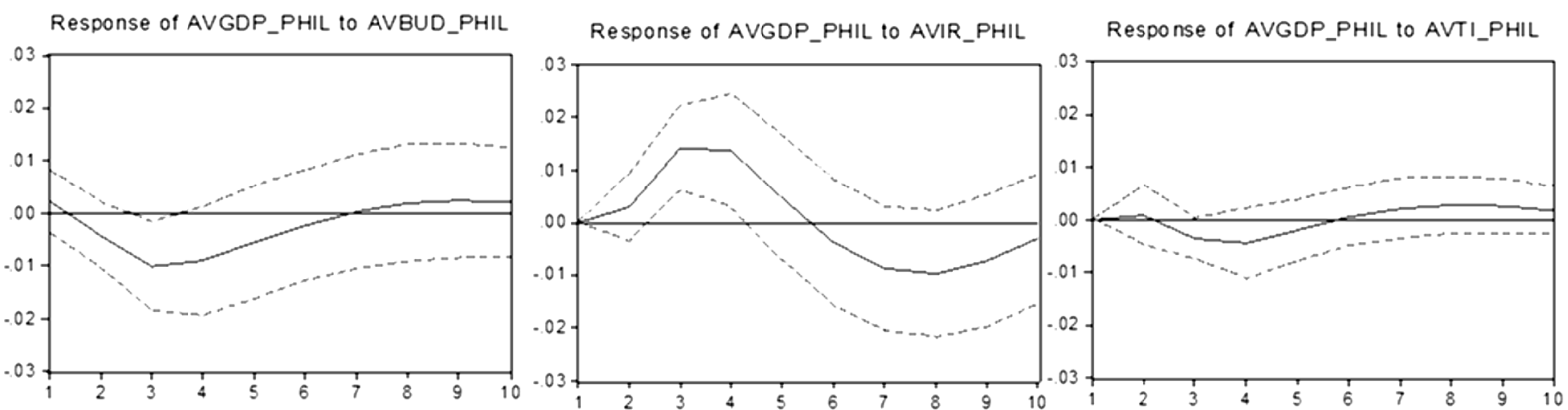

Gambar 4. Impulse Response Filipina

8 selanjutnya bergerak stabil.

Pengujian impulse response untuk Thailand dapat dilihat pada Gambar 5. Apabila dilihat dari respon variabel GDP terhadap koordinasi kebijakan fiskal maka ketika ada shock dari kenaikan koordinasi kebijakan fiskal maka dampaknya terhadap GDP mula-mula mengalami peningkatan signifikan dan mencapai puncaknya pada periode ke 3 dan selanjutnya mengalami penurunn sampai periode ke 8 dan selanjutnya stabil sampai periode ke 10 .

Hasil pengujian untuk respon variabel GDP terhadap koordinasi kebijakan moneter memperlihatkan bahwa ketika ada shock dari kenaikan koordinasi kebijakan moneter maka dampaknya terhadap GDP mula-mula mengalami kenaikan dan mencapai puncaknya pada periode ke 4 dan selanjutnya mengalami penurunan sampai periode ke 9 dan kemudian stabil sampai periode 10. Dilihat dari respon variabel GDP terhadap variabel intensitas perdagangan maka ketika ada shock dari kenaikan intensitas perdagangan, dampaknya terhadap GDP mulamula mengalami kenaikan sampai periode ke 3 dan selanjutnya mengalami penurunan sampai titik puncaknya pada periode ke 7 selanjutnya bergerak stabil sampai periode 10 .

Hasil pengujian impulse response untuk Jerman dapat dilihat pada Gambar 6. Apabila dilihat dari respon variabel GDP terhadap koordinasi kebijakan fiskal maka ketika ada shock dari kenaikan koordinasi kebijakan fiskal maka dampaknya terhadap GDP mula-mula stabil sampai periode ke 4 dan selanjutnya meningkat sampai periode 7 dan stabil sampai periode 10. Walaupun kenaikannya semakin lama semakin besar sampai dengan periode ke 8 namun kenaikan tersebut tidak mencapai titik keseimbangan.

Dilihat dari respon variabel GDP terhadap koordinasi kebijakan moneter memperlihatkan bahwa ketika ada shock dari kenaikan koordi-

Response to Cholesky One S.D. Innovations \pm 2 S.E.

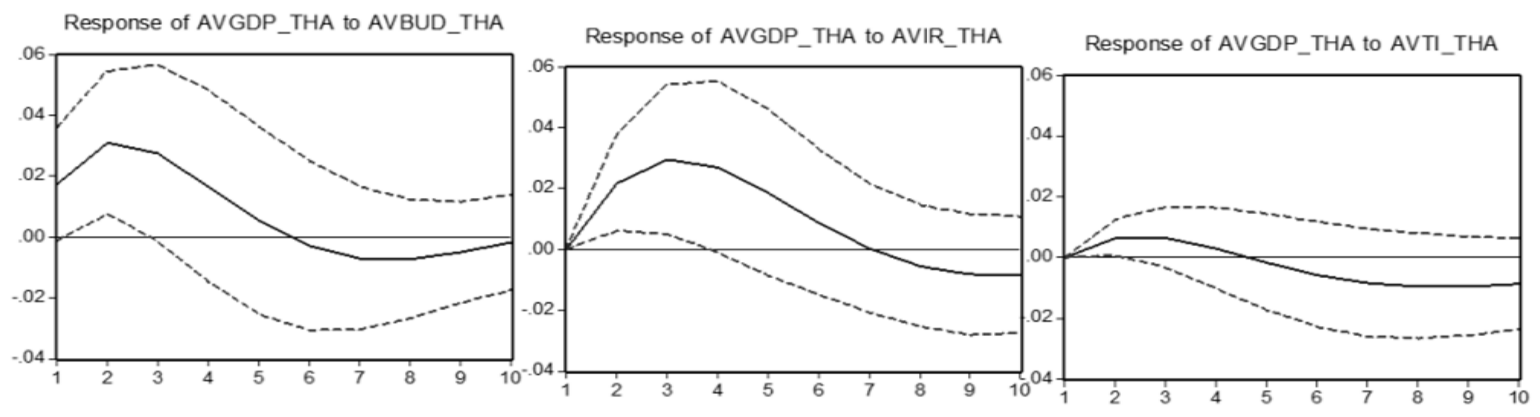

Gambar 5. Impulse Response Thailand 
Response to Cholesky One S.D. Innovations \pm 2 S.E.

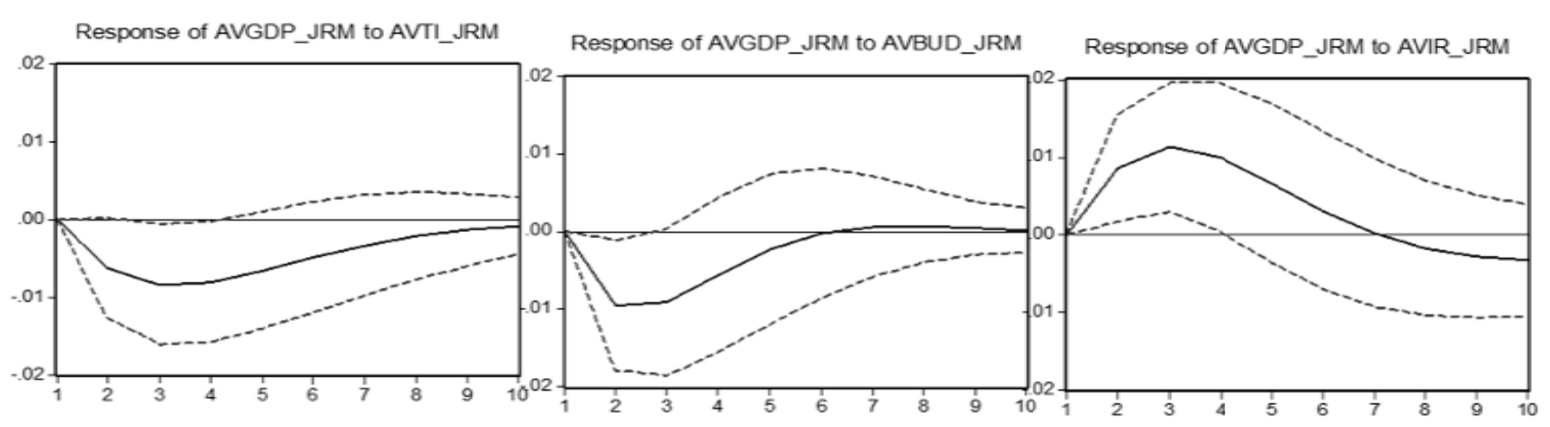

Gambar 6. Impulse Response Jerman

nasi kebijakan moneter maka dampaknya terhadap GDP mula-mula mengalami penurunan pada periode ke 2 dan selanjutnya meningkat sampai puncaknya pada periode ke 6 dan selanjutnya mengalami penurunan sampai periode 10. Dilihat dari respon variabel GDP terhadap variabel intensitas perdagangan maka adalah ketika ada shock dari kenaikan intensitas perdagangan maka dampaknya terhadap GDP mula-mula mengalami kenaikan hingga puncaknya pada periode 4 selanjutnya mengalami penurunan sampai periode ke 10.

Pengujian impulse response untuk Belanda dapat dilihat pada Gambar 7. Apabila dilihat dari respon variabel GDP terhadap koordinasi kebijakan fiskal maka ketika ada shock dari kenaikan koordinasi kebijakan fiskal, dampaknya terhadap GDP mula-mula mengalami penurunan signifikan periode ke 3 dan selanjutnya mengalami peningkatan sampai periode ke 6 dan selanjutnya stabil sampai periode ke 10 .

Dilihat dari respon variabel GDP terhadap koordinasi kebijakan moneter adalah ketika ada shock dari kenaikan koordinasi kebijakan moneter maka dampaknya terhadap GDP mula-mula mengalami kenaikan dan mencapai puncaknya pada periode ke 5 dan selanjutnya mengalami penurunan sampai periode ke 10. Hasil pengujian untuk respon variabel GDP terhadap variabel intensitas perdagangan maka adalah ketika ada shock dari kenaikan intensitas perdagangan maka dampaknya terhadap GDP mulamula mengalami kenaikan sampai periode ke 3 dan selanjutnya mengalami penurunan sampai periode 10 .

\section{Variance Decomposition dari GDP}

Variance decomposition memisahkan variasi perubahan shock dari setiap variabel terhadap variabel lain dalam model. Setiap variabel per-

Response to Cholesky One S.D. Innovations \pm 2 S.E.
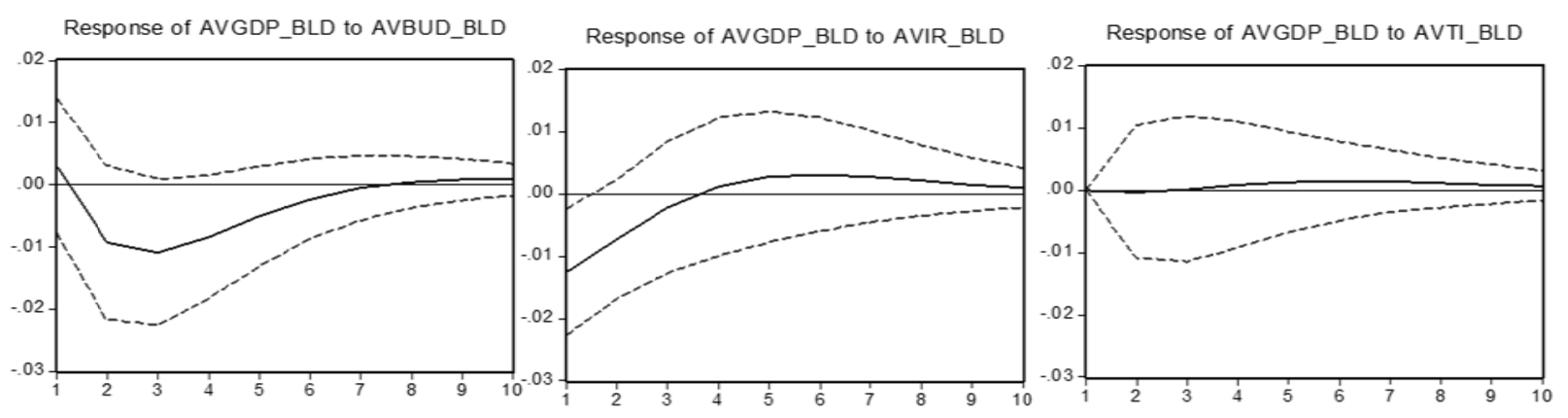

Gambar 7. Impulse Response Belanda 
Tabel 9. Variance Decomposition untuk Indonesia

\begin{tabular}{cccccc}
\hline Period & S.E. & GDP_BLD & MPC_BLD & TI_BLD & FPC_BLD \\
\hline 1 & 0,028541 & 100,0000 & 0,000000 & 0,000000 & 0,000000 \\
2 & 0,035516 & 89,88222 & 0,385265 & 0,030031 & 9,702483 \\
3 & 0,038544 & 81,48699 & 1,104525 & 0,027709 & 17,38078 \\
4 & 0,039720 & 77,15924 & 1,876643 & 0,045297 & 20,91882 \\
- & n & n & &
\end{tabular}

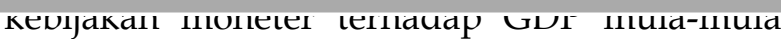
hanya sebesar 0,38 persen pada periode ke 2 dan terus mengalami kenaikan sampai periode ke 10. Sementara itu kontribusi shock variabel intensitas perdagangan terhadap GDP sebesar 0,03 persen, setelah itu kontribusinya selalu mengalami kenaikan, sampai dengan periode periode ke 10 yaitu sebesar 0,49 persen. Kontri-

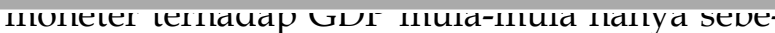
sar 2,52 persen pada periode ke 2 dan terus mengalami kenaikan sampai periode ke 6 yaitu sebesar 17 persen dan selanjutnya menurun sampai periode ke 10 (16,6 persen). Sementara itu kontribusi shock variabel intensitas perdagangan terhadap GDP sebesar 0,97 persen, setelah itu kontribusinya selalu mengalami

Tabel 10. Variance Decomposition untuk Malaysia

\begin{tabular}{cccccc}
\hline Period & S.E. & FPC_MAS & GDP_MAS & MPC_MAS & TI_MAS \\
\hline 1 & 0,237512 & 0,168657 & 99,83134 & 0,000000 & 0,000000 \\
2 & 0,327378 & 1,192972 & 95,30811 & 2,526539 & 0,972379 \\
3 & 0,354370 & 9,424666 & 79,48570 & 10,35083 & 0,738799 \\
4 & 0,360753 & 17,87807 & 65,44979 & 15,58287 & 1,089280 \\
5 & 0,366248 & 19,68199 & 61,87384 & 16,97681 & 1,467368 \\
6 & 0,369106 & 19,70937 & 61,78758 & 17,02548 & 1,477565 \\
7 & 0,369630 & 20,86289 & 60,66870 & 16,80561 & 1,662793 \\
8 & 0,369796 & 21,48339 & 59,70991 & 16,69912 & 2,107581 \\
9 & 0,369934 & 21,36548 & 59,56000 & 16,65885 & 2,415665 \\
10 & 0,370196 & 21,44062 & 59,45229 & 16,60745 & 2,499643 \\
\hline \multicolumn{7}{c}{}
\end{tabular}


Tabel 11. Variance Decomposition untuk Filipina

\begin{tabular}{cccccc}
\hline Period & S.E. & FPC_PHIL & GDP_PHIL & MPC_PHIL & TI_PHIL \\
\hline 1 & 0,144985 & 1,924340 & 98,07566 & 0,000000 & 0,000000 \\
2 & 0,256274 & 7,000694 & 90,22077 & 2,540931 & 0,237602 \\
3 & 0,316142 & 19,59702 & 45,90825 & 32,39062 & 2,104111 \\
4 & 0,344977 & 22,46082 & 31,60184 & 42,33314 & 3,604199 \\
5 & 0,358730 & 24,21914 & 30,14031 & 41,86855 & 3,772009 \\
6 & 0,370967 & 24,07214 & 30,15341 & 42,08368 & 3,690769 \\
7 & 0,384813 & 22,25961 & 28,10797 & 45,82072 & 3,811698 \\
8 & 0,395540 & 20,58613 & 25,61352 & 49,68879 & 4,111550 \\
9 & 0,401628 & 19,92850 & 24,45036 & 51,23928 & 4,381865 \\
10 & 0,405617 & 19,93354 & 24,39648 & 51,15955 & 4,510428 \\
\hline
\end{tabular}

kenaikan, sampai dengan periode periode ke 10 yaitu sebesar 2,49 persen. Kontribusi shock variabel kebijakan fiskal terhadap GDP sebesar 0,16 persen pada periode ke 1, setelah itu kontribusinya selalu mengalami kenaikan, sampai dengan periode periode ke 10 yaitu sebesar 21,4 persen (Tabel 10).

Hasil analisis untuk pengujian Filipin ketahui bahwa variance decomposition dari v bel GDP menjelaskan bahwa pada periode dipengaruhi oleh variabel itu sendiri yait persen. Namun pada periode ke 2 nilainya menurun sampai 24,39 persen pada period Kontribusi shock variabel koordinasi kebij moneter terhadap GDP mula-mula $h$ sebesar 2,54 persen pada periode ke 2 dan mengalami kenaikan sampai periode $k_{\imath}$ yaitu sebesar 51,16 persen. Sementara kontribusi shock variabel intensitas perdagangan terhadap GDP sebesar 0,23 persen, setelah itu kontribusinya selalu mengalami kenaikan, sampai dengan periode periode ke 10 yaitu sebesar 4,51 persen. Kontribusi shock variabel kebijakan fiskal terhadap GDP sebesar 1,92 persen pada periode ke 1, setelah itu kontribusinya selalu mengalami kenaikan sekitar 0,3 persen sampai dengan periode ke 10 yaitu sebe-

Tabel 12. Variance Decomposition untuk Thailand

\begin{tabular}{cccccc}
\hline Period & S.E. & FPC_THA & GDP_THA & MPC_THA & TI_THA \\
\hline 1 & 0,189425 & 11,74819 & 88,25181 & 0,000000 & 0,000000 \\
2 & 0,229417 & 24,92954 & 64,89364 & 9,373195 & 0,803622 \\
3 & 0,245407 & 28,76772 & 50,87793 & 19,19426 & 1,160082 \\
4 & 0,252262 & 28,54002 & 44,62672 & 25,71852 & 1,114742 \\
5 & 0,255801 & 27,56776 & 42,71509 & 28,61953 & 1,097620 \\
6 & 0,258478 & 27,13426 & 42,45672 & 28,95242 & 1,456600 \\
7 & 0,261120 & 27,14929 & 42,22856 & 28,39113 & 2,231019 \\
8 & 0,263846 & 27,10699 & 41,60910 & 28,08304 & 3,200880 \\
9 & 0,266573 & 26,81080 & 40,83662 & 28,22813 & 4,124451 \\
10 & 0,269218 & 26,40833 & 40,17833 & 28,53847 & 4,874873 \\
\hline \multicolumn{7}{c}{ Cholesky Ordering: FPC_THA GDP_THA MPC_THA TI_THA } \\
\hline
\end{tabular}


Tabel 13. Variance Decomposition untuk Jerman

\begin{tabular}{cccccc}
\hline Period & S.E. & GDP_JRM & TI_JRM & FPC_JRM & MPC_JRM \\
\hline 1 & 0,022592 & 100,0000 & 0,000000 & 0,000000 & 0,000000 \\
2 & 0,027838 & 73,57500 & 5,020612 & 11,87000 & 9,534390 \\
3 & 0,032525 & 53,91095 & 10,37029 & 16,63002 & 19,08873 \\
4 & 0,035470 & 45,71102 & 13,90497 & 16,53048 & 23,85353 \\
5 & 0,036821 & 42,77757 & 16,11182 & 15,75429 & 25,35633 \\
6 & 0,037292 & 41,82742 & 17,40897 & 15,36598 & 25,39763 \\
7 & 0,037448 & 41,49042 & 18,06069 & 15,25955 & 25,18935 \\
8 & 0,037560 & 41,24979 & 18,28948 & 15,19746 & 25,26327 \\
9 & 0,037701 & 40,96983 & 18,28383 & 15,09347 & 25,65288 \\
10 & 0,037861 & 40,66109 & 18,17714 & 14,96597 & 26,19580 \\
\hline \multicolumn{7}{c}{}
\end{tabular}

tribusinya selalu mengalami kenaikan, sampai dengan periode periode ke 10 yaitu sebesar 4,87 persen. Kontribusi shock variabel kebijakan fiskal terhadap GDP sebesar 11,74 persen, setelah itu kontribusinya selalu mengalami kenaikan sekitar 13 persen sampai dengan periode ke 10 yaitu sebesar 26,40 persen (Tabel 12).

Dari hasil analisis untuk pengujian Jerman untuk keempat variabelnya sangat fluktuatif. Pengujian variance decomposition dari variabel GDP menjelaskan bahwa pada periode bahwa variabel GDP dipengaruhi oleh variabel sendiri yaitu sebesar 100 persen. Sementara itu kontribusi shock variabel koordinasi kebijakan moneter terhadap GDP mula-mula hanya sebesar 9,53 persen pada periode ke 2 dan terus mengalami kenaikan sampai periode ke 10 (26,19 persen). Sementara kontribusi shock variabel intensitas perdagangan terhadap GDP sebesar 5,02 persen, setelah itu kontribusinya selalu mengalami kenaikan, sampai dengan periode periode ke 10 yaitu sebesar 18,17 persen. Kontribusi shock variabel kebijakan fiskal terhadap GDP sebesar 11,87 persen pada periode ke 1, setelah itu kontribusinya selalu mengalami kenaikan hingga puncaknya pada periode ke 3 sebesar 16,6 persen dan kemudian terus menurun hingga periode periode ke 10 yaitu sebesar 14,9 persen (Tabel 13).

Dari hasil analisis untuk pengujian Belanda dimulai dari pengujian variance decomposition dari variabel GDP yang menjelaskan bahwa pada periode bahwa variabel GDP dipengaruhi oleh variabel sendiri yaitu sebesar 99,8 persen. Sementara itu kontribusi shock variabel koordinasi kebijakan moneter terhadap GDP mulamula hanya sebesar 0,38 persen pada periode ke 2 dan terus mengalami kenaikan sampai periode ke 10 (3,15 persen). Sementara itu kontribusi shock variabel intensitas perdagangan

Tabel 14. Variance Decomposition untuk Belanda

\begin{tabular}{cccccc}
\hline Period & S.E. & GDP_BLD & MPC_BLD & TI_BLD & FPC_BLD \\
\hline 1 & 0,028541 & 100,0000 & 0,000000 & 0,000000 & 0,000000 \\
2 & 0,035516 & 89,88222 & 0,385265 & 0,030031 & 9,702483 \\
3 & 0,038544 & 81,48699 & 1,104525 & 0,027709 & 17,38078 \\
4 & 0,039720 & 77,15924 & 1,876643 & 0,045297 & 20,91882 \\
5 & 0,040165 & 75,50121 & 2,485618 & 0,121467 & 21,89171 \\
6 & 0,040381 & 75,01061 & 2,860496 & 0,234939 & 21,89396 \\
7 & 0,040522 & 74,86564 & 3,046203 & 0,343550 & 21,74461 \\
8 & 0,040616 & 74,78516 & 3,121131 & 0,422461 & 21,67125 \\
9 & 0,040672 & 74,72034 & 3,145280 & 0,469271 & 21,66511 \\
10 & 0,040701 & 74,67478 & 3,150931 & 0,492750 & 21,68154 \\
\hline
\end{tabular}

Cholesky Ordering: GDP_BLD MPC_BLD TI_BLD FPC_BLD 
terhadap GDP sebesar 0,03 persen, setelah itu kontribusinya selalu mengalami kenaikan, sampai dengan periode periode ke 10 yaitu sebesar 0,49 persen. Kontribusi shock variabel kebijakan fiskal terhadap GDP sebesar 9,7 persen pada periode ke 1, setelah itu kontribusinya selalu mengalami kenaikan, sampai dengan periode periode ke 10 yaitu sebesar 21,68 persen (Tabel 14).

\section{SIMPULAN}

Meningkatnya intensitas perdagangan bukan merupakan persyaratan mutlak yang menjamin terjadinya keselarasan siklus bisnis di ASEAN4. Meningkatnya keselarasan siklus bisnis juga banyak dipengaruhi oleh variabel lain terutama koordinasi kebijakan moneter. Hasil kajian ini mengimplikasikan pentingnya mata uang bersama khususnya untuk negara-negara yang sudah terintegrasi perekonomiannya seperti ASEAN-4. Asumsinya, biaya yang dikeluarkan suatu negara yang sudah bergabung dalam mata uang bersama akan menurun apabila intensitas perdagangan semakin meningkat (Shin dan Wang, 2004; Frankel dan Rose, 1998; Rana, 2007).

Hasil pengujian VAR memperlihatkan bahwa empat kriteria pengujian kelambanan optimal (LR, FPE, AIC, dan HQ) pada sembilan negara merekomendasikan lag optimal sebesar dua kuartal. Dengan hasil tersebut maka kelambanan (lag) optimal yang disarankan dipakai dalam model VAR adalah sebesar satu kuartal. Sementara itu hasil perhitungan VAR secara keseluruhan diketahui bahwa seluruh variabel memiliki nilai koefisien determinasi antara 27 persen sampai 94 persen, artinya sebanyak lebih dari 56 persen variasi variabel independen mampu menjelaskan variabel dependennya.

Pengembangan model penelitian empiris dalam penelitian ini masih menyisakan keterbatasan yang dapat dikemukakan sebagai berikut: (1) Sampel yang digunakan adalah ASEAN-4 atau kurang dari separuh dari anggota keseluruhan ASEAN dengan pertimbangan ketersediaan data penelitian dalam rentang periode 1980-2008 sehingga hasil penelitian tidak dapat dijeneralisasi sebagai perilaku ASEAN. Untuk penelitian yang akan datang mungkin akan lebih baik dilakukan penelitian dengan sampel seluruh negara ASEAN sehingga lebih mewakili keberadaan ASEAN seutuhnya. Sementara itu untuk Uni Eropa yang diwakili oleh Jerman dan Belanda juga tidak dapat mencerminkan perilaku Uni Eropa secara keseluruhan. (2) Perilaku data yang tidak stabil menjadi fenomena tersendiri karena akan memberikan interpretasi hasil yang berbeda, bias, bahkan tidak sesuai dengan teori. Hal ini sangat menyulitkan peneliti. Shock akibat krisis ekonomi tahun 1998 menyebabkan hasil yang berbeda. Saran untuk penelitian yang akan datang adalah mengeliminir data yang anomali akibat terjadinya shock ekonomi; dan (3) Variabel yang dipakai dalam penelitian ini adalah variabel bentukan dan cukup rumit sehingga menimbulkan kesulitan dalam hal justifikasi dan definisi operasional variabel. Peneliti yang akan datang dapat menggunakan variabel sekunder yang tersedia atau jika tetap ingin menggunakan variabel bentukan harus bekerja lebih keras untuk dapat meyakinkan pembaca dalam memahami hasil penelitiannya.

\section{Ucapan Terima Kasih}

Terima kasih banyak disampaikan kepada DIKTI yang telah memberikan beasiswa penelitian dalam skim Hibah Doktor 2009 dan Lembaga Penelitian Universitas Diponegoro yang telah memfasilitasi penelitian ini.

\section{DAFTAR PUSTAKA}

Achsani, Noer Azam. 2008. Integrasi Ekonomi ASEAN+3: Antara Peluang dan Ancaman. Artikel. diakses dari http://www.brighten.or.id/index.php?view $=$ article\&catid $=40$ :noer-azam-achsani\&id=64: integrasiekonomi-asean3-antara-peluang-danancaman\&tmpl $=$ component\&print $=1$ \&page $=$ pada tanggal 21 Januari 2009

ASEAN Secretariat, ASEAN Database Trade, 2007. diakses dari http://www.aseansec. org/64. htm.

Botha, Ilse. 2004. Modelling the Business Cycle of 
South Africa: Linear VS Non Linear Methods. Disertasi. Rand Afrikaans University.

Cortinhas, Carlos. 2007. Intra Industry Trade and Business Cycle in ASEAN. Journal of Applied Economic. Vol. 39. 893-902

Eric C.Y. Ng. 2007. Vertical Specialization, Intra industry Trade and Business Cycle Comovement. Working Paper. Minneapolis: Federal Reserve Bank of Mineapolis

Fiess, Norbert. 2005. Business Cycle Syncronization and Regional Integration: A Case Study for Central America. Working Paper. diakses dari www.worldbank.org. Tanggal 23 Januari 2009.

Frankel, Jeffrey, and Andrew Rose. 1998. The Endogeneity of the Optimum Currency Area Criteria. Economic Journal 108 (449): 1009-25.

Greene, W.H. 2000. Econometric Analysis, Fourth Edition. New Jersey: Prentice Hall.

Gujarati, Damodar. 2003. Basic Econometric, Columbus: McGraw-Hill, Inc.

Hadi, Yonathan S. 2003. Analisis Vector Auto Regression (VAR) terhadap Korelasi Antara Pendapatan Nasional dan Investasi Pemerintah di Indonesia, 1983/1984 - 1999/2000. Jurnal Keuangan dan Moneter. Volume 6 Nomor 2 Desember 2003.

Handoyo, Rossanto. D. 2002. Permintaan Uang M1 di ASEAN-4, Indonesia, Malaysia, Singapura dan Thailand, Estimasi Data Non Stasioner, 1981.1-1999.4. Thesis. Universitas Gadjah Mada. Tidak dipublikasikan.

Kuncoro, Mudrajad. 2007. Metode Kuantitatif; Teori dan Aplikasi untuk Bisnis dan Ekonomi. Edisi Ketiga. Yogyakarta: Unit Penerbit dan Percetakan STIM YKPN.
Loayza, Norman. Humberto López and Angel Ubide. 2001. Comovement and Sectoral Interdependence: Evidence for Latin America, East Asia, and Europe. IMF Staff Papers. Vol. 48, No. 2, pp. 367-396.

Mittal, Rashi. 2004. ASEAN Monetary Union - a Possibility? A Comparison of ASEAN Economic Indicators with that of Euro Zone. Thesis. California: Public Policy Department Stanford University.

Rana, Pradumna.B. 2007. Trade Intensity and Business Cycle Syncronization: The Case of East Asia. Working Paper Series on Regional Economic Integration. No.10. Asian Development Bank.

Shin, Kwanho dan Yunjong Wang. 2004. Trade Integration and Business Cycle Synchronization in East Asia. Asian Economic Papers

Syamsudin dan Anton A Setyawan. 2008. Foreign Direct Investment (Fdi), Kebijakan Industri, dan Masalah Pengangguran: Studi Empirik di Indonesia. Jurnal Ekonomi Pembangunan FE UMS. Vol. 9, No.1, Juni 2008, hal. 107 119. Surakarta: BPPE.UMS.

Teng, Kwek Kian dan Way, Cho Cho. 2005. Trade Integration and Business Cycle Syncronization: The Case of India, China with ASEAN5. didownload dari www. pes.org.ph/faea/ downloads/paper/3/pararell3b1.pdf pada tanggal 9 Januari 2009.

Unair, Fakultas Ekonomi. 2009. Modul Pelatihan Ekonometrika Vector Autoregression. Surabaya: Universitas Airlangga

Zebregs, Harm. 2004. Intraregional Trade in Emerging Asia. IMF Policy Discussion Paper. 